\title{
Review Article \\ Phytoceuticals in Acute Pancreatitis: Targeting the Balance between Apoptosis and Necrosis
}

\author{
Laura Gaman, ${ }^{1}$ Dorin Dragos $\left(\mathbb{D},{ }^{1,2}\right.$ Adelina Vlad $\left(\mathbb{D},{ }^{1}\right.$ Georgiana Catalina Robu, ${ }^{1}$ \\ Mugurel Petrinel Radoi, ${ }^{1,3}$ Laura Stroica, ${ }^{1}$ Mihaela Badea, ${ }^{4}$ and Marilena Gilca (iD ${ }^{1}$ \\ ${ }^{1}$ Faculty of General Medicine, Carol Davila University of Medicine and Pharmacy, B-dul Eroilor Sanitari No. 8, Sector 6, \\ 76241 Bucharest, Romania \\ ${ }^{2}$ Nephrology Clinic, University Emergency Hospital Bucharest, 050098 Bucharest, Romania \\ ${ }^{3}$ National Institute of Neurology and Neurovascular Diseases, Bucharest, Romania \\ ${ }^{4}$ Transilvania University of Braşov, Braşov, Romania
}

Correspondence should be addressed to Marilena Gilca; marilenagilca@gmail.com

Received 25 September 2017; Revised 29 November 2017; Accepted 20 December 2017; Published 4 March 2018

Academic Editor: Silvia Wein

Copyright (C) 2018 Laura Gaman et al. This is an open access article distributed under the Creative Commons Attribution License, which permits unrestricted use, distribution, and reproduction in any medium, provided the original work is properly cited.

Despite recent advances in understanding the complex pathogenesis of pancreatitis, the management of the disease remains suboptimal. The use of phytoceuticals (plant-derived pleiotropic multitarget molecules) represents a new research trend in pancreatology. The purpose of this review is to discuss the phytoceuticals with pancreatoprotective potential in acute pancreatitis and whose efficacy is based, at least in part, on their capacity to modulate the acinar cell death. The phytochemicals selected, belonging to such diverse classes as polyphenols, flavonoids, lignans, anthraquinones, sesquiterpene lactones, nitriles, and alkaloids, target the balance between apoptosis and necrosis. Activation of apoptosis via various mechanisms (e.g., inhibition of X-linked inhibitor of apoptosis proteins by embelin, upregulation of FasL gene expression by resveratrol) and/or inhibition of necrosis seem to represent the essential key for decreasing the severity of the disease. Apart from targeting the apoptosis/necrosis balance, the phytochemicals displayed other specific protective activities: inhibition of inflammasome (e.g., rutin), suppression of neutrophil infiltration (e.g., ligustrazine, resveratrol), and antioxidant activity. Even though many of the selected phytoceuticals represent a promising therapeutic alternative, there is a shortage of human evidence, and further studies are required to provide solid basis to justify their use in the treatment of pancreatitis.

\section{Introduction}

Despite recent advances in understanding the pathogenesis of pancreatitis and identification of new therapeutic solutions, the management of the disease, especially that of severe acute pancreatitis (SAP), remains suboptimal, and this clinical form is still associated with a high mortality rate [1-4]. Several studies reported values between $25 \%$ and $35 \%$ in case of pancreatitis complicated with persistent organ failure $[5,6]$.

Pancreatitis is an inflammatory disease associated also with important parenchymal cell death [7]. It involves escape of abnormally activated intra-acinar protease zymogens and lipase, into the interstitium of the pancreas, causing autodigestion of the pancreatic tissue [8,9]. It is often complicated with systemic inflammation and multiorgan dysfunction syndrome.

The current therapeutic guidelines for acute pancreatitis (AP) include the following: intravenous fluid replacement, dietary changes, analgesics, inhibitors of pancreatic secretion (somatostatin and its analogue, octreotide), L-arginine, calcium ion antagonists, and different inflammatory mediator inhibitors [10-13].

Unfortunately, the use of standard drugs in acute pancreatitis is still disappointing. Also, the available drugs (somatostatin and octreotide) have a short half-life and their clinical efficiency is limited $[14,15]$. Hence, there is renewed interest in phytomedicines, which lack severe adverse effects and 
TABLE 1: Animal models of pancreatitis.

\begin{tabular}{|c|c|c|c|}
\hline Chemical inducer & Characteristics & Pancreatitis type & References \\
\hline Bile salts & $\begin{array}{l}\text { Mechanical temporary blockage of bile duct, detergent effect of the } \\
\text { bile salts, and hemorrhagic necrosis }\end{array}$ & Severe AP & {$[16]$} \\
\hline Cerulein & $\begin{array}{l}\text { Stimulation of pancreatic enzyme production, inhibition of zymogen } \\
\text { granules exocytosis, NADPH oxidase activation, increased reactive } \\
\text { oxygen species generation, NF- } \kappa \text { B activation, cytokine expression, } \\
\text { and acinar cells death }\end{array}$ & $\begin{array}{c}\text { Mild AP } \\
\text { CP (repeated exposure) }\end{array}$ & {$[17-19]$} \\
\hline L-arginine & $\begin{array}{l}\text { Increased production of amylase, lipase, and trypsinogen, markedly } \\
\text { swollen mitochondria, and degenerative changes of intracellular } \\
\text { organelles and nuclei }\end{array}$ & $\begin{array}{l}\text { Severe necrotizing AP } \\
\text { CP }\end{array}$ & {$[20,21]$} \\
\hline $\begin{array}{l}\text { Alcohol }+/- \text { high fat } \\
\text { diet }\end{array}$ & Stellate cell activation, fibrosis, and acinar cell mass shrinkage & Mild CP & {$[22-24]$} \\
\hline Dibutyltin dichloride & $\begin{array}{l}\text { Edema }(24 \mathrm{~h}) \text {, mononuclear cells infiltration (day } 7) \text {, bile duct } \\
\text { epithelium necrosis, upregulation of transforming growth factor- } \beta 1 \text {, } \\
\text { and fibrosis with increased collagen type I production }\end{array}$ & $\begin{array}{l}\mathrm{AP} \\
\mathrm{CP}\end{array}$ & {$[25]$} \\
\hline CCK & $\begin{array}{l}\text { Increased plasma amylase, lipase, trypsin-like immunoreactivity, } \\
\text { pancreatic parenchymal swelling, and interlobular and subcapsular } \\
\text { fluid accumulation }\end{array}$ & AP & {$[26]$} \\
\hline
\end{tabular}

AP: acute pancreatitis, CCK: cholecystokinin, and CP: chronic pancreatitis.

may have benefits not only regarding the symptoms but also regarding the disease evolution.

Various animal models of pancreatitis have been used to study the properties of both medicinal plants extracts and individual phytochemicals, used alone or in combination (Table 1).

The purpose of this review is to summarize the available scientific information obtained from medical databases and literature on phytochemicals that have been reported to have therapeutic potential in acute pancreatitis, whose efficacy is based, at least in part, on their capacity to modulate the acinar cell death.

\section{Methodology}

A literature search was performed using the following phrases "phytochemicals AND acute pancreatitis OR pancreas", "medicinal plant OR herb AND acute pancreatitis OR pancreas", and "specific phytochemical name AND pancreatitis or pancreas" (e.g., resveratrol AND pancreatitis OR pancreas), in PubMed and Elsevier database.

Selection Criteria. Relevant studies (in vitro and/or on animal models and/or on human subjects) found in PubMed and Elsevier databases were collected regardless of study design, language, year of publication, or publication status. Standardized criteria were utilized for selection. At least one in vitro or animal study investigating the effect of the phytocompound on the apoptosis of pancreatic acinar cells in an experimental model of acute pancreatitis was inclusion criterion.

Data Analysis. Data extraction and analysis were performed by professionals conducting medical research or clinical work at academic level. The most significant results for our subject were retrieved. Data were verified by a second author.

Relevant phytochemicals are presented in an alphabetical order: artemisinin, baicalin, crambene, curcumin, embelin, emodin, hesperidin, honokiol, ligustrazine, magnolol, naringin, nordihydroguaiaretic acid, resveratrol, rhein, and rutin.

\section{Key Aspects of Pancreatitis Pathogenesis}

3.1. Inflammatory Response in Pancreatitis. A plenty of studies showed that proinflammatory cytokines (e.g., TNF- $\alpha$, IL$1 \beta$, and IL-6) are key factors in AP pathogenesis and progression towards systemic complications [27-29]. The stress kinases ERK (extracellular signal-regulated kinase), JNK (cjun N-terminal kinase), and p38, which are members of the mitogen-activated protein kinase (MAPK) cascade, seem to play an important role in pancreatic overproduction of these proinflammatory cytokines [30, 31]. Therefore, inhibitors or activators of ERK, p38, and JNK can modulate the tissue damage in animal models of pancreatitis [32].

Other factors (e.g., platelet activating factor (PAF,) pancreatic polypeptide, peptide $Y Y$, substance $P$, intestinal gut dysfunction, and endotoxinemia) were cited as contributors to the pathogenesis of pancreatitis and of its complications [33-36]. For instance, PAF, an inflammatory mediator involved in the processes leading to pancreatitis, has ubiquitous receptors (on pancreatic islet cells [37], pancreatic microvascular endothelium [38], bronchia epithelial cells [37], and leukocytes [39]) and therefore could amplify both the local and the systemic inflammatory response $[36,40]$.

Several studies suggested that upregulation of toll-like receptor 4 (TLR4), constitutively expressed in pancreas, as well as in other tissues (e.g., leukocytes, endothelial cells, lung, kidney, and heart) may play a role in the local pancreatic injury and in the systemic inflammatory response, through stimulation of cytokine synthesis [41-44].

In addition to acinar cells and lymphocytes, there are also a few other cell categories that represent key actors in the scenario of pancreatitis pathogenesis. Several families of macrophages, which are activated during different stages of AP, are involved in the disease progression: 
peritoneal macrophages (pMФs), Kupffer cells, and alveolar macrophages $[45,46]$. Pancreatic stellate cells (PSCs), activated as a response to pancreatic injury or inflammation via transforming growth factor- $\beta$ (TGF- $\beta$ ), are multifunctional cells which play a crucial profibrogenic role in chronic pancreatitis. It is already established that PSCs are involved in inflammation, apoptosis, insulin expression, and exocrine function in the pancreas [47].

3.2. Parenchymal Cell Death in Pancreatitis. Despite significant progress in revealing the molecular mechanisms of inflammatory response in pancreatitis, little is known about the pathways of parenchymal cell death [7].

Apoptosis and necrosis represent the two main types of cell death: the "good" (environment-friendly) and the "bad" (environment-spoiling), respectively, because apoptosis, by contrast to necrosis, does not elicit an inflammatory response and hence does not injure the surrounding cells [48]. Moreover, apoptosis seems to generally limit the inflammatory cascade, having an active protective effect $[49,50]$. These may explain why enhancing apoptosis reduces the severity of AP $[51,52]$ (the apoptosis-to-necrosis ratio being high in mild AP and low in SAP [53]). Interestingly, the mechanisms by which somatostatin analogue octreotide relieves acute pancreatitis in mice seem to be correlated with the induction of apoptosis in pancreatic acinar cells [54].

Nevertheless, apoptosis role is dual, being dependent on its intensity. Pancreatic acinar cells undergoing apoptosis, as well as necrosis, can release damage-associated molecular patterns (DAMPs), such as histones, DNA, and heat shock proteins (HSP). Apoptotic cell remnants are rapidly phagocytosed [55], while necrotic cell remnants are less efficiently removed $[7,56]$. When the rate of DAMPs phagocytosis is surpassed by the rate of apoptosis, the accumulated DAMPs, which have proinflammatory effects, may aggravate the pancreatic injury [49].

There are two main distinct signalling pathways leading to apoptosis:

Extrinsic pathway: initiated by the activation of death receptors, like TNF receptor or Fas receptor, and mediated by caspase- 8 , which eventually activates caspase- 3

Intrinsic pathway (a.k.a. mitochondrial pathway): initiated by reactive oxidative species (ROS), hypoxia, and so forth; it requires the disruption of the mitochondrial membrane, which leads to the release of cytochrome c, known to be involved in the activation of caspase-9, which further activates caspase-3 [7].

Caspases, cysteine proteases that act in cascade, are classified into two categories: initiator caspases (e.g., caspase2 , caspase- 8 , caspase- 9 , and caspase-10) and effector caspases (e.g., caspase-3, caspase-6, and caspase-7), depending on their position and role in apoptosis pathway [57].

The permeabilization of the outer mitochondrial membrane responsible for cytochrome $\mathrm{c}$ release is regulated by the Bcl-2 family members, which are either antiapoptotic (e.g., Bcl-2) or proapoptotic (e.g., Bax, Bak) [58]. Inhibitor of apoptosis proteins (IAPs) represent another category of apoptosis regulatory agents that bind to and inhibit caspases. For instance, X-linked IAP (XIAP) was found to be involved in the caspase blockade in pancreatitis [7], and its deletion decreased the severity of AP via regulation of cell death (enhanced apoptosis and reduced necrosis in pancreatic acinar cells) and nuclear factor- $\kappa \mathrm{B}$ activity [59]. High doses of colecistokinin-8 (CCK-8) induced apoptosis in isolated pancreatic acinar cells, by releasing cytochrome $\mathrm{c}$ and consequent activation of caspase- 9 , caspasese-3, and caspase-8 [60].

Other apoptosis pathways seem to be involved in pancreatitis pathogenesis. One of them is the p53-mediated apoptosis pathway, which involves formation of PIDDsome, a complex consisting of PIDD (p53-induced protein with death domain), RAIDD (RIP-associated ICH-1/CED-3 homogenous protein with death domain), and procaspase-2 [61]. PIDD expression is controlled by p53 [62]. PIDDsome assembling results in caspase-2 activation [63], which directly activates effector caspases [64], leading to apoptosis [65]. Nevertheless, there are studies indicating that apoptosis may develop without caspase activation. These alternative pathways seem to be mediated by mitochondrial factors, like apoptosis-inducing factor (AIF), endonuclease G (endoG), and so forth [66], but it is not yet clarified if these pathways are involved in pancreatitis pathogenesis.

There are also two distinct signalling pathways leading to necrosis:

Extrinsic pathway: initiated by the activation of death receptors, similarly to apoptosis extrinsic pathway, but differently mediated, by TNFR1 complex II and receptor-interacting protein kinases (RIPKs)

Intrinsic pathway (initiated by severe cellular stress producing a mitochondrial dysfunction that eventually leads to ATP depletion and increased oxidative stress) [7].

Several members of RIPK family, such as RIPK1 and RIPK3, contribute to parenchymal cell death through necrosis in pancreatitis $[67,68]$. It is already established that the activity of RIPK3 is correlated with responsiveness to TNFalpha induced necrosis [67]. As a consequence of cell lysis, the intracellular content is released in the intercellular matrix, eventually reaching systemic circulation, and DAMPs may trigger local and systemic inflammation [68]. Toll-like receptors (TLRs) sense endogenous danger signals, represented by DAMPs, and mediate the aggravation of pancreatic injury and inflammatory response (Figure 1).

The major pathway of apoptosis is generally considered to be the intrinsic one, in contrast with necrosis main modality, which is mostly extrinsic [52]. Necrosis is either spontaneous or tightly regulated. The best investigated form of regulated necrosis is called necroptosis [69] and is mediated by the receptor-interacting protein kinases RIPK1/RIPK3/mixed lineage kinase domain-like pathway [67]. Interestingly, necroptosis is the major form of acinar cell death in several experimental models of pancreatitis, and its blockage not only might prevent pancreatitis but also might decrease the severity, when this is already established $[69,70]$.

There are other ways of cell death, like pyroptosis, which is a form of highly inflammatory lytic programmed cell death. Inflammasomes, innate immune system receptors and sensors [71], activate caspase-1 or caspase-11/4/5, leading eventually to the formation of large pores in the membrane, responsible for cell swelling and membrane rupture $[69,72]$. 


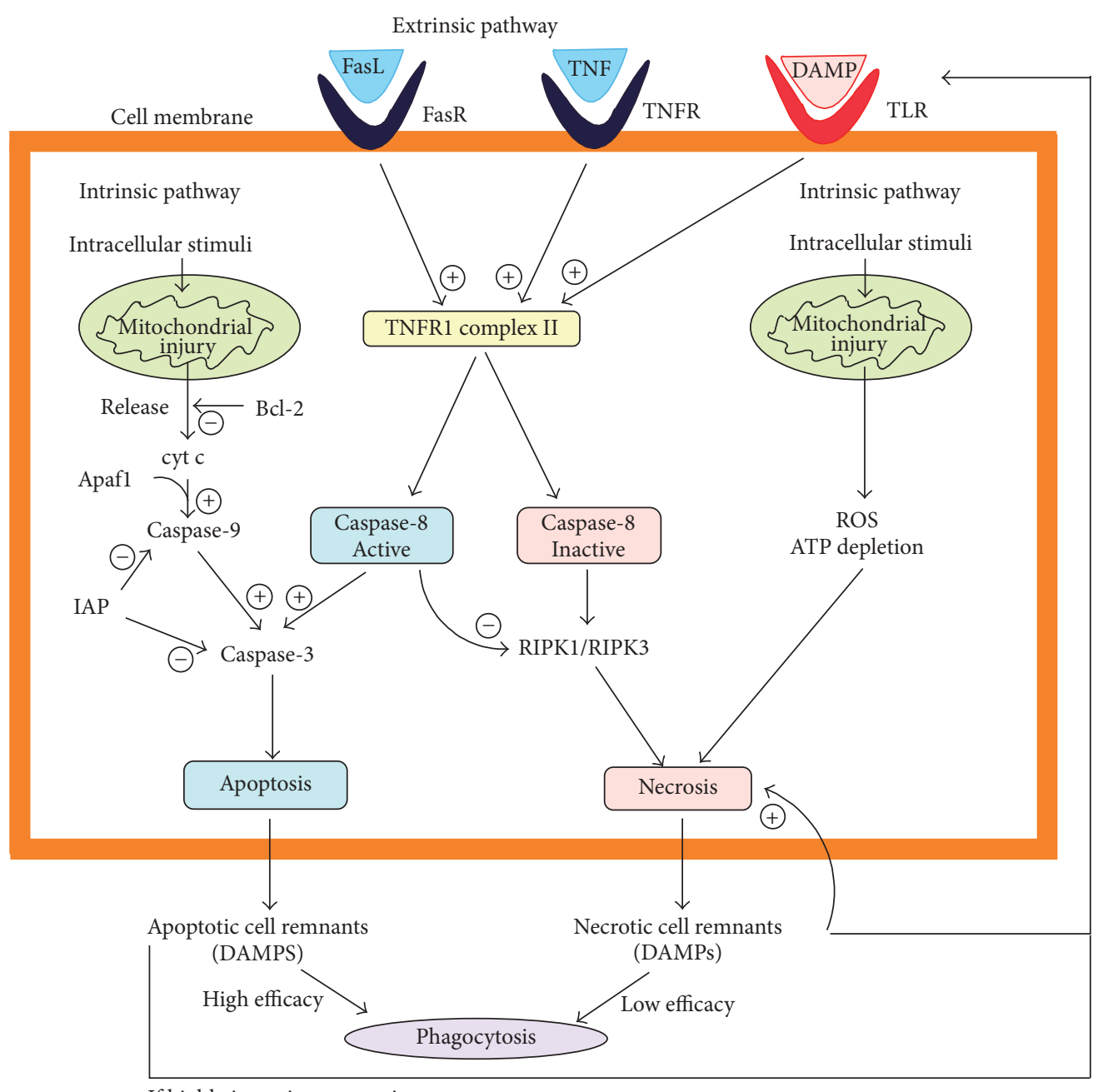

If highly intensive apoptosis

FIGURE 1: Mechanisms underlying the balance between apoptosis and necrosis in acute pancreatitis (FasL: Fas ligand, FasR: Fas receptor, IAP: inhibitor of apoptosis proteins, DAMP: damage-associated molecular patterns, RIPK: receptor-interacting protein kinases, TLR: toll-like receptors, and TNFR: TNF receptor).

When the inflammasome pathway is impaired (e.g., genetic deletion of various components such as TLR9), the cell death rate and inflammation in pancreatitis are decreased $[73,74]$.

3.3. Calcium and Cell Death in Acute Pancreatitis. It has been demonstrated that $\mathrm{Ca}^{2+}$ elevation in the acinar cells cytoplasm leads to the intracellular activation of digestive enzymes and the ensuing physiopathological cascade characteristic for AP. Moreover, the pattern of $\mathrm{Ca}^{2+}$ elevation (sustained high level versus fluctuating lower level) may influence the severity of AP [the normal one being (very) low (i.e., normal) level, fluctuating under the influence of various physiologic stimuli, which elicit short-lived increases, sufficient only to drive the extracellular release of the digestive enzymes, but insufficient in magnitude and duration for their activation]. A major stressor infringing upon the acinar cells provokes a sustained, marked increase in cytosolic $\mathrm{Ca}^{2+}$, which leads to persistent mitochondrial depolarization [possibly by opening the mitochondrial permeability transition pore (MPTP)]. This results in a drastic ATP shortage that knocks out the energy-hungry $\mathrm{Ca}^{2+}$ pumps, leading to $\mathrm{Ca}^{2+}$ accumulation in the cytoplasm [with simultaneous depletion of the endoplasmic reticulum (ER)], inappropriate uncontrolled activation of digestive enzymes that wreak havoc in the cell, culminating with $\mathrm{Ca}^{2+}$-dependent necrosis. On the other hand, a more subdued aggression elicits a lower level and undulating increase in cytosolic $\mathrm{Ca}^{2+}$, leading to ephemeral MPTP opening and hence to only partial mitochondrial depolarization, ROS generation, and activation of the intrinsic (mitochondrial) pathway of apoptosis. Thus the cell's death is peaceful and modestly consequential [75]. Preventing $\mathrm{Ca}^{2+}$ from piling up in the cytosol may seem a promising strategy for mitigating AP.

There are differences between various animal models of pancreatitis, in terms of necrosis/apoptosis ratio and caspase activation degree: the rat model of cerulein pancreatitis is characterized by relatively high apoptosis and low necrosis as well as strong activation of caspases, while the mouse model by low apoptosis and high necrosis associated with a lack of caspase activation [7]. The necrosis/apoptosis ratio was 
120 -fold greater in the mouse model than in the rat model. Caspase inhibition worsened necrosis (resulting in higher amylase and lipase) and inflammatory cell infiltration in rat cerulein pancreatitis, while caspase activation decreased necrosis and normalized pancreatic histology in mouse cerulein pancreatitis, suggesting that caspases are involved not only in induction of apoptosis but also in protection against necrosis [7].

3.4. Cross-Talk between Apoptosis, Necrosis, and Inflammatory Pathways in Acute Pancreatitis. It is worth mentioning that there is a significant cross-talk between the apoptosis and necrosis signalling pathways involved in pancreatitis pathogenesis:

(1) Cross-talk between extrinsic and intrinsic pathways of apoptosis, such as indirect activation of caspase8 via the intrinsic pathway, following activation of caspase-3 [76], or activation of $\mathrm{BH} 3$ interactingdomain death agonist, a proapoptotic member of the $\mathrm{Bcl}-2$ protein family, by caspase- 8 dependent cleavage (extrinsic apoptotic pathway), resulting in cytochrome c release (intrinsic apoptotic pathway) [52]

(2) Cross-talk between apoptosis and necrosis signalling pathways, such as activation of both pathways through death receptors by the same death ligands (e.g., binding of TNF- $\alpha$ to TNFR) [52] or inactivation of RIPK (necrosis pathway) through proteolytic cleavage by caspase- 8 (apoptosis pathway) [77].

3.5. Oxidative Stress and Pancreatitis. Oxidative stress is an important pathogenic factor placed at the crossroads between apoptosis, necrosis, and inflammation pathways.

Pancreatic islet cells showed lower levels of antioxidant enzymes and represent a target for heavy metals accumulation (e.g., cadmium); therefore pancreas is more susceptible to oxidative stress than other tissues and organs [78-80]. Pancreas is also highly prone to injury consequent to ischemia produced by various mechanisms (e.g., decreased blood flow induced by ethanol, specific microcirculatory anatomy, and microvascular changes due to acute injuries), followed by reperfusion (which is associated with an increased synthesis of ROS and inflammatory reaction) [81, 82].

Oxidative stress leads to the activation of nuclear factor kappa-light-chain-enhancer of activated B cells $(\mathrm{NF}-\kappa \mathrm{B})$ and PI3K/AKT signalling pathways which is also critically involved in generating the inflammatory side of pancreatitis as well as its complications [83-86]. NADPH oxidase activation and increased synthesis of free radicals represent other contributors to the pathogenesis of pancreatitis. The degree of NADPH oxidase activity was positively correlated to the severity of pancreatic oxidative alteration in AP [87].

\section{Proapoptotic Phytochemicals with Protective Effects in Pancreatitis}

Phytoceuticals represent an attractive therapeutic alternative in pancreatitis, more and more patients, as well as scientists, focusing either their personal or scientific interest on the potential benefits of these bioactive plant-derived products (see Table 2). Interestingly, a recent cross-sectional survey of consecutive outpatients seen at a Pancreas Center found that $44 \%$ of the patients with pancreatic disorders used complementary and alternative medicines (CAM) (medicinal plants representing $28 \%$ of the total CAM), the percentage being even higher $(47 \%)$ in patients with previous acute pancreatitis [88].

The purpose of this review was to elaborate a hypothesis concerning the potential efficacy of phytoceuticals in acute pancreatitis, which might be based on multitargeting the balance between apoptosis and necrosis, as well as inflammation and oxidative stress.

4.1. Artemisinin and Its Derivatives. Artemisinin is a sesquiterpene lactone identified in sweet wormwood (Artemisia annua, fam. Asteraceae), in the 1970s, by a Chinese group led by $\mathrm{Tu}$ et al. [135]. Its discovery was awarded Nobel Prize in 2015, due to its excellent contribution to human health, having mainly antimalarial but also other important bioactivities (e.g., anti-inflammatory, immunoregulatory, and anticancer bioactivities) [136-139]. Its derivatives such as artesunate, hydroartemisinin, artemether, and arteether have been used to treat malaria in clinical settings.

\subsubsection{In Vitro Studies}

Inflammation. Artesunate, a water-soluble hemisuccinate derivative of dihydroartemisinin, substantially inhibited the expression of IL- $1 \beta$, IL-6, TLR4, and NF- $\kappa$ B p65 in the pancreatic acinar cells treated with lipopolysaccharide (LPS), but it did not significantly influence the TNF- $\alpha$ release [90].

\subsubsection{Animal Studies}

Apoptosis versus Necrosis. Artemisinin relieved the severity of inflammation in cerulein-induced AP in Wistar rats, by increasing the number of apoptotic cells and caspase-3 activity, while reducing the number of necrotic cells and the level of serum amylase [89]. In another study, the SD rats treated with various doses of artesunate showed significantly milder parenchymal necrosis and hemorrhage than the SAP group [90].

Inflammation. Artemisinin decreased pancreatic edema and inflammatory cell infiltration, NF- $\kappa$ B-activation, MIP- $1 \alpha$ protein, myeloperoxidase (MPO), and IL-1 $\beta$ mRNA in cerulein-induced AP of Wistar rats [89]. Artesunate was also found to increase the survival of rats with $3.5 \%$ sodium taurocholate-induced SAP, ameliorating their pancreatic histological alterations (necrosis and hemorrhages), decreasing serum amylase and lipase activities, and pancreatic release of proinflammatory cytokines (IL-1 $\beta$ and IL-6) [90].

4.2. Baicalin. Baicalin is a flavone glucuronide known and used as an anti-inflammatory agent [140]. It is extracted from Scutellaria spp. (skullcap), fam. Lamiaceae (particularly from S. baicalensis) and from Erigeron breviscapus, fam. Asteraceae $[140,141]$. 
TABLE 2: Phytoceuticals effects in acute pancreatitis (animal studies) and their proposed mechanism of action.

\begin{tabular}{|c|c|c|c|c|}
\hline $\begin{array}{l}\text { Animals/cell type } \\
\text { used }\end{array}$ & $\begin{array}{l}\text { Dose, route of } \\
\text { administration, } \\
\text { duration of the study }\end{array}$ & AP model & Findings & Ref. \\
\hline \multicolumn{5}{|c|}{ Artemisinin (sesquiterpene lactone) found in Artemisia annua, fam. Asteraceae and its derivatives } \\
\hline Male Wistar rats & $50 \mathrm{mg} / \mathrm{kg}$ artemisinin & $\begin{array}{l}\text { i.p. } 20 \mu \mathrm{g} / \mathrm{kg} \text { cerulein, } 4 \mathrm{inj} . \\
\text { at } 1 \mathrm{~h} \text { interval }\end{array}$ & $\begin{array}{l}\uparrow \text { apoptosis, caspase- } 3 \text {, } \\
\downarrow \text { necrosis, amylase, pancreatic edema, } \\
\text { inflammatory cell infiltration, NF- } \kappa \text { B, } \\
\text { MPO, MIP- } 1 \alpha \text { protein, IL- } 1 \beta \text { mRNA }\end{array}$ & [89] \\
\hline Male SD rats & $\begin{array}{l}0.70,1.75 \text { and } 3.50 \mathrm{mg} / \mathrm{kg} \\
\text { artesunate }\end{array}$ & $\begin{array}{l}\text { r.i.BPD } 3.5 \% \text { sodium } \\
\text { taurocholate }\end{array}$ & $\begin{array}{l}\uparrow \text { survival rate } \\
\downarrow \text { pancreatic necrosis, hemorrhage, } \\
\text { amylase, lipase, pancreatic release of } \\
\text { IL-1 } \beta \text { and IL-6 }\end{array}$ & {$[90]$} \\
\hline \multicolumn{5}{|c|}{ Baicalin (flavone glucuronide) found in Scutellaria spp., fam. Lamiaceae } \\
\hline SD rats & $\begin{array}{l}\text { 5\%, i.v.b. } 10 \mathrm{mg} / 100 \mathrm{~g} \\
\text { f.c.i.v.i. } 10 \mathrm{mg} / \mathrm{h} / 100 \mathrm{~g}\end{array}$ & $\begin{array}{l}\text { r.i.BPD } 3.5 \% \text { sodium } \\
\text { taurocholate }\end{array}$ & $\begin{array}{l}\downarrow \text { renal pathological changes, mortality, } \\
\text { renal Bcl-2 protein, serum NO, plasma } \\
\text { endotoxin, serum BUN, IL-6, ET-1, } \\
\text { TNF- } \alpha \text {, PLA2. } \\
\uparrow \text { renal apoptotic indexes, Bax protein }\end{array}$ & [91] \\
\hline Male SD rats & $\begin{array}{l}5 \% \text {, i.v.b. } 10 \mathrm{mg} / 100 \mathrm{~g} \\
\text { f.c.i.v.i. } 10 \mathrm{mg} / \mathrm{h} / 100 \mathrm{~g}\end{array}$ & $\begin{array}{l}\text { r.i.BPD } 3.5 \% \text { sodium } \\
\text { taurocholate }\end{array}$ & $\begin{array}{l}\downarrow \text { TNF- } \alpha, \text { P-selectin, } \uparrow \text { caspase-3 }(\uparrow \\
\text { apoptosis) }\end{array}$ & {$[92]$} \\
\hline SD rats & $\begin{array}{l}5 \% \text {, i.v.b. } 10 \mathrm{mg} / 100 \mathrm{~g} \\
\text { f.c.i.v.i. } 10 \mathrm{mg} / \mathrm{h} / 100 \mathrm{~g}\end{array}$ & $\begin{array}{l}\text { r.i.BPD 3.5\% sodium } \\
\text { taurocholate }\end{array}$ & $\begin{array}{l}\downarrow \text { mortality, endotoxin, TNF- } \alpha \\
\uparrow \text { Bax protein, apoptosis index }\end{array}$ & [93] \\
\hline SD rats & $\begin{array}{l}5 \% \text {, i.v.b. } 10 \mathrm{mg} / 100 \mathrm{~g} \\
\text { f.c.i.v.i. } 10 \mathrm{mg} / \mathrm{h} / 100 \mathrm{~g}\end{array}$ & $\begin{array}{l}\text { r.i.BPD } 3.5 \% \text { sodium } \\
\text { taurocholate }\end{array}$ & $\begin{array}{l}\downarrow \text { mortality, pathological severity scores, } \\
\text { plasma endotoxin, serum PLA2, ET-1, } \\
\text { NO, P-selectin }\end{array}$ & [94] \\
\hline \multicolumn{5}{|c|}{ Crambene (nitrile) found in brussels sprouts and other plants from fam. Cruciferae } \\
\hline Female CD-1 mice & i.v.b. $70 \mathrm{mg} / \mathrm{kg}$ & $\begin{array}{l}\text { i.p. } 50 \mu \mathrm{g} / \mathrm{kg} \text { cerulein, } 12 \mathrm{inj} . \\
\text { at } 1 \mathrm{~h} \text { interval }(4,12,24,48 \\
\text { hours after pre-trt.) }\end{array}$ & $\begin{array}{l}\downarrow \text { amylase, pancreatic edema, necrosis } \\
\text { (12 h after pre-trt.) } \\
\uparrow \text { apoptosis, caspase- } 3,-8,-9\end{array}$ & {$[51]$} \\
\hline Male Swiss mice & i.v.b. $70 \mathrm{mg} / \mathrm{kg}$ & $\begin{array}{l}\text { i.p. } 50 \mu \mathrm{g} / \mathrm{kg} \text { cerulein, } \\
3 / 6 / 10 \mathrm{inj} . \text { at } 1 \mathrm{~h} \text { interval ( } 12 \\
\text { hours after pre-trt.) }\end{array}$ & $\begin{array}{l}\uparrow \text { apoptosis } \\
\downarrow \text { MCP-1, IL- } 1 \beta, \text { TNF- } \alpha \\
\uparrow \text { IL-10, TGF- } \beta 1\end{array}$ & [95] \\
\hline \multicolumn{5}{|c|}{ Curcumin (polyphenol/diarylheptanoid) found in Curcuma longa, fam. Zingiberaceae } \\
\hline Albino rats & $\begin{array}{l}\text { i.p. } 50 \mathrm{mg} / \mathrm{kg} / \mathrm{d} \times 6 \mathrm{~d} \\
\text { (pre-AP induction, post-AP } \\
\text { induction or no-AP } \\
\text { induction, resp.) }\end{array}$ & $\begin{array}{l}250 \mathrm{mg} / 100 \mathrm{~g} \mathrm{~L} \text {-arginine } \\
\text { i.p., twice at an interval of } \\
1 \mathrm{~h}\end{array}$ & $\begin{array}{l}\downarrow \text { amylase, lipase, NAP78, protein } \\
\text { carbonyls, TNF- } \alpha \text {, MPO, pancreatic fgl-2 } \\
\uparrow \text { caspase- } 3 \text { (apoptosis) }\end{array}$ & {$[96]$} \\
\hline Male SD rats & i.p. $100 \mathrm{mg} / \mathrm{kg}$ & $\begin{array}{l}\text { r.i.BPD 5\% sodium } \\
\text { taurocholate }\end{array}$ & $\begin{array}{l}\downarrow \text { ascites, amylase, TNF- } \alpha \text {, TLR } 4, \text { NF- } \kappa \text { B, } \\
\text { IL-10 }\end{array}$ & [97] \\
\hline WA rats & $\begin{array}{l}\text { i.g. } 100 \mathrm{mg} / \mathrm{kg} \text { (curcumin in } \\
\text { alcohol) } 20 \mathrm{~d} \text { before AP } \\
\text { induction and all through } \\
\text { the study }\end{array}$ & $\begin{array}{l}\text { r.i.BPD } 3 \% \text { sodium } \\
\text { taurocholate }\end{array}$ & $\begin{array}{l}\downarrow \text { total histopathologic scores, trypsin } \\
\text { activity, NF- } \kappa \text { B, AP- } 1 \text {, chemokine, TNF- } \alpha \text {, } \\
\text { IL- } 6 \text {, iNOS, NO } \\
\uparrow \text { caspase-3 activity }\end{array}$ & [98] \\
\hline Kun Ming male mice & i.p. $50 \mathrm{mg} / \mathrm{kg} / \mathrm{d} \times 6 \mathrm{~d}$ & i.p. $50 \mu \mathrm{g} / \mathrm{kg}$ cerulein & $\begin{array}{l}\downarrow \text { pancreas injury, amylase, ALT, AST, } \\
\text { TNF- } \alpha, \text { NF- } \kappa \text { B-p } 65 \\
\uparrow \text { PPAR } \gamma\end{array}$ & [99] \\
\hline Male SD rats & i.v. $35 \mathrm{mg} / \mathrm{kg} / \mathrm{h} \times 6 \mathrm{~h}$ & $\begin{array}{l}\text { i.v. cerulein }(5 \mu \mathrm{g} / \mathrm{kg} / \mathrm{h}) \times \\
6 \mathrm{~h} \text { and i.g.ethanol diet } \times \\
6 \mathrm{wk} \rightarrow \text { i.v. CCK-8 } \\
(3 \mathrm{nmol} / \mathrm{kg} / \mathrm{h}) \times 6 \mathrm{~h}\end{array}$ & $\begin{array}{l}\downarrow \text { pancreas injury (histologic changes, } \\
\text { amylase, trypsin, neutrophil infiltration) } \\
\downarrow \text { NF- } \kappa \mathrm{B} \text { ( } \downarrow \text { I } \kappa \mathrm{B} \text { degradation), AP-1, IL-6, } \\
\text { TNF- } \alpha \text {, chemokine KC, iNOS }\end{array}$ & [100] \\
\hline Male SD rats & i.p. $20 \mathrm{mg} / \mathrm{kg}$ & $\begin{array}{l}2 \mathrm{~h} \text { ischemia } \rightarrow 6 \mathrm{~h} \\
\text { reperfusion }\end{array}$ & $\begin{array}{l}\downarrow \text { amylase, } \mathrm{HO}^{\bullet}, \mathrm{NO}, \mathrm{TNF}-\alpha \text {, WBC } \\
\text { count; } \\
\text { (lung) } \downarrow \text { iNOS, TNF- } \alpha \text {, hyperreactivity }\end{array}$ & [101] \\
\hline
\end{tabular}


TABLE 2: Continued.

\begin{tabular}{|c|c|c|c|c|}
\hline $\begin{array}{l}\text { Animals/cell type } \\
\text { used }\end{array}$ & $\begin{array}{l}\text { Dose, route of } \\
\text { administration, } \\
\text { duration of the study }\end{array}$ & AP model & Findings & Ref. \\
\hline \multicolumn{5}{|c|}{ Embelin (benzoquinone derivative) found in Ardisia japonica, fam. Primulaceae, Embelia ribes Burm, fam. Primulaceae } \\
\hline $\begin{array}{l}\text { Male SD rats and } \\
\text { male Swiss Webster } \\
\text { CD-1 mice }\end{array}$ & s.c. $20 \mathrm{mg} / \mathrm{kg} \times 5 \mathrm{~d}$ & i.p. $50 \mu \mathrm{g} / \mathrm{kg}$ cerulein & $\begin{array}{l}\downarrow \text { pancreatic necrosis and } \uparrow \text { apoptosis in } \\
\text { mouse model, } \uparrow \text { caspase- } 9,-3,-8 \text { in } \\
\text { mouse model }\end{array}$ & [7] \\
\hline \multicolumn{5}{|c|}{$\begin{array}{c}\text { Emodin (anthraquinone) found in Rheum spp., fam. Polygonaceae, Rhamnus spp., fam. Rhamnaceae, Fallopia japonica, fam. } \\
\text { Polygonaceae }\end{array}$} \\
\hline Male SD rats & i.v. $2.5 \mathrm{mg} / \mathrm{kg} \mathrm{q} 6 \mathrm{~h}$ & $\begin{array}{l}\text { r.i.BPD } 5 \% \text { sodium } \\
\text { taurocholate }\end{array}$ & $\uparrow$ pancreatic blood flow & {$[102]$} \\
\hline Male SD rats & i.v. $2.5 \mathrm{mg} / \mathrm{kg} \mathrm{q} 6 \mathrm{~h}$ & $\begin{array}{l}\text { r.i.BPD } 5 \% \text { sodium } \\
\text { taurocholate }\end{array}$ & $\begin{array}{l}\downarrow \text { TXB2 } \\
\uparrow \text { 6-keto-PGF1 } \alpha \text {, PGE2 } \downarrow \text { mortality, } \\
\text { pancreatic pathologic scoring }\end{array}$ & {$[102]$} \\
\hline Male SD rats & i.v. $2.5 \mathrm{mg} / \mathrm{kg} \mathrm{q} 6 \mathrm{~h}$ & $\begin{array}{l}\text { r.i.BPD } 5 \% \text { sodium } \\
\text { taurocholate }\end{array}$ & $\begin{array}{l}\downarrow \text { TXB2 } \\
\uparrow \text { 6-keto-PGF1 } \alpha \text {, PGE2 } \\
\downarrow \text { mortality, amylase, lipase, ascites, } \\
\text { pancreatic edema, inflammation, } \\
\text { necrosis, bleeding, microthrombosis }\end{array}$ & {$[103]$} \\
\hline Male SD rats & i.v. $2.5 \mathrm{mg} / \mathrm{kg}$ & $\begin{array}{l}\text { r.i.BPD } 5 \% \text { sodium } \\
\text { taurocholate }\end{array}$ & $\begin{array}{l}\downarrow \text { TNF- } \alpha \text {, IL- } 6 \text {, edema, extravasation, } \\
\text { histological score } \\
\uparrow \text { claudin-5, occludin }\end{array}$ & {$[104]$} \\
\hline Male SD rats & i.v. $2.5 \mathrm{mg} / \mathrm{kg}$ & $\begin{array}{l}\text { r.i.BPD } 5 \% \text { sodium } \\
\text { taurocholate }\end{array}$ & $\begin{array}{l}\downarrow \text { TNF- } \alpha \text {, IL-6, MPO, pulmonary } \\
\text { extravasation \& edema; } \uparrow \text { claudin- } 4 \text {, } \\
\text { claudin-5, occludin }\end{array}$ & {$[105]$} \\
\hline Male SD rats & $\begin{array}{l}\text { orally } 20 / 40 / 80 \mathrm{mg} / \mathrm{kg} \times 28 \\
\text { days }\end{array}$ & $\begin{array}{l}\text { r.i.BPD trinitrobenzene } \\
\text { sulfonic acid }\end{array}$ & $\begin{array}{l}\downarrow \text { TGF- } \beta 1 \text {, pancreatic fibrosis, glandular } \\
\text { atrophy, collagen, fibronectin, laminin }\end{array}$ & {$[106]$} \\
\hline SD rats & i.v. $2.5 \mathrm{mg} / \mathrm{kg}$ & $\begin{array}{l}\text { r.i.BPD } 3.5 \% \text { sodium } \\
\text { taurocholate }\end{array}$ & $\begin{array}{l}\uparrow \text { intestinal transit } \\
\downarrow \text { TNF- } \alpha, \text { IL-1 } \beta, \text { NF- } \kappa \text { B-p65 }\end{array}$ & {$[107]$} \\
\hline SD rats & i.v. $2.5 \mathrm{mg} / \mathrm{kg}$ & $\begin{array}{l}\text { r.i.BPD } 3.5 \% \text { sodium } \\
\text { taurocholate }\end{array}$ & $\begin{array}{l}\downarrow \text { amylase, histological damage, edema, } \\
\text { vacuolization, inflammation, necrosis, } \\
\text { NF- } \kappa \text { B activation, TNF- } \alpha \text {, IL-6, IL- } 1 \beta \text {, } \\
\text { MDA } \\
\uparrow \text { SOD }\end{array}$ & {$[108]$} \\
\hline SD rats & i.v. $2.5 \mathrm{mg} / \mathrm{kg}$ & $\begin{array}{l}\text { r.i.BPD } 1.5 \% \text { sodium } \\
\text { deoxycholate }\end{array}$ & $\uparrow \mathrm{mCD} 14$ \& ICAM-3 expression in pMФs & {$[109,110]$} \\
\hline SD rats & i.v. $2.5 \mathrm{mg} / \mathrm{kg}$ & $\begin{array}{l}\text { r.i.BPD } 1.5 \% \text { sodium } \\
\text { ursodeoxycholate }\end{array}$ & $\begin{array}{l}\downarrow \text { amylase, lung edema, pathological } \\
\text { changes, serum TNF- } \alpha \text {, SAP-induced } \\
\text { acute lung injury } \\
\uparrow \text { AQP1 and AQP5 } \\
\text { improved blood gases indexes }\end{array}$ & {$[111]$} \\
\hline SD rats & i.v. $2.5 \mathrm{mg} / \mathrm{kg}$ & r.i.BPD 3\% sodium cholate & $\begin{array}{l}\downarrow \text { apoptosis of intestinal mucosa cells, } \\
\text { translocation of bacteria and endotoxin } \\
\uparrow \text { serum leptin, intestinal barrier function }\end{array}$ & {$[112]$} \\
\hline RPA AR42J cells & 10 and $20 \mu \mathrm{M}$ & $\begin{array}{l}\text { cerulein }\left(10^{-7} \mathrm{M}\right)+ \\
\text { lipoplysaccharide }(10 \mathrm{mg} / \mathrm{l})\end{array}$ & $\begin{array}{l}\downarrow \text { amylase } \\
\uparrow \text { apoptotic indices \& } \downarrow \text { necrosis }(\downarrow \\
\text { necrosis/apoptosis ratio); } \downarrow \text { calcium } \\
\text { overload in the cytoplasm } \\
\downarrow \text { ER stress transducers }\end{array}$ & {$[113]$} \\
\hline \multicolumn{5}{|c|}{ Emodin $(E M)+$ baicalin $(B A) /$ baicalein $(B A e)$} \\
\hline Male SD rats & $\begin{array}{l}\text { i.v. } 2.5 \mathrm{mg} / \mathrm{kg} \text { for } \mathrm{EM} \text {, } \\
20 \mathrm{mg} / \mathrm{kg} \text { for BA }\end{array}$ & $\begin{array}{l}\text { r.i.BPD } 5 \% \text { sodium } \\
\text { taurocholate }\end{array}$ & $\begin{array}{l}\downarrow \text { amylase, TNF- } \alpha \text {, IL- } 6 \text {, TLR } 4 \text { expression } \\
\text { in pancreas and lung, pancreatic and } \\
\text { pulmonary damage }\end{array}$ & {$[44]$} \\
\hline Male SD rats & $\begin{array}{l}\text { i.v. } 2.5 \mathrm{mg} / \mathrm{kg} / 6 \mathrm{~h} \text { for } \mathrm{EM} \text {, } \\
20 \mathrm{mg} / \mathrm{kg} / 6 \mathrm{~h} \text { for BA }\end{array}$ & $\begin{array}{l}\text { r.i.BPD } 5 \% \text { sodium } \\
\text { taurocholate }\end{array}$ & $\begin{array}{l}\downarrow \text { mortality, ascites, pancreatic } \\
\text { pathological scores, amylase, TNF- } \alpha \text {, IL- } 6\end{array}$ & {$[114]$} \\
\hline
\end{tabular}


TABLE 2: Continued.

\begin{tabular}{|c|c|c|c|c|}
\hline $\begin{array}{l}\text { Animals/cell type } \\
\text { used }\end{array}$ & $\begin{array}{l}\text { Dose, route of } \\
\text { administration, } \\
\text { duration of the study }\end{array}$ & AP model & Findings & Ref. \\
\hline \multicolumn{5}{|c|}{$\operatorname{Emodin}(E M)+E E N$} \\
\hline Male Wistar rats & $\begin{array}{l}\mathrm{EM}(3.0 \mathrm{mg} / 100 \mathrm{~g}) \text { by } \\
\text { enteral tube } \mathrm{q} 10 \mathrm{~h} \times 6 \text { times }\end{array}$ & $\begin{array}{l}\text { r.i.BPD } 5 \% \text { sodium } \\
\text { taurocholate }\end{array}$ & $\begin{array}{l}\downarrow \text { amylase, ALT, AST, MDA, hepatic \& } \\
\text { pancreatic MPO, TNF- } \alpha \text {, AngII, CRP, } \\
\text { endotoxin, lactate, mortality, pathological } \\
\text { changes, ascites }\end{array}$ & {$[115]$} \\
\hline \multicolumn{5}{|c|}{ Hesperidin (flavone) found in citrus fruits } \\
\hline WA rats & $0.3 \mathrm{~g} / \mathrm{kg}$ s.c. & $\begin{array}{l}\text { cerulein } 50 \mu \mathrm{g} / \mathrm{kg} \text { hourly } 7 \\
\text { times }\end{array}$ & $\begin{array}{l}\downarrow \text { amylase, inflammatory infiltrate, } \\
\text { edema, ROS burden, NO }\end{array}$ & {$[116]$} \\
\hline RPA AR42J cells & $53.7 \mu \mathrm{g} / \mathrm{L}$ hesperidin & cerulein & $\begin{array}{l}\uparrow \text { cell viability, apoptosis index; } \downarrow \\
\text { necrosis, LDH released from the cells, } \\
\text { ROS generation }\end{array}$ & {$[117]$} \\
\hline \multicolumn{5}{|c|}{ Honokiol (lignan) found in Magnolia officinalis (Magnoliaceae) } \\
\hline RPA AR42J cells & $9.07 \mu \mathrm{g} / \mathrm{L}$ honokiol & cerulein & $\begin{array}{l}\uparrow \text { cell viability, apoptosis index; } \downarrow \\
\text { necrosis, LDH released from the cells }\end{array}$ & {$[118]$} \\
\hline \multicolumn{5}{|c|}{ Ligustrazine (tetramethylpyrazine) found in Ligusticum wallichii, fam. Umbeliferae } \\
\hline Adult SD rats & $\begin{array}{l}\text { i.p. } 150 \mathrm{mg} / \mathrm{kg} / \mathrm{day}, 3 \text { days } \\
10 \mathrm{~min} \text { after the first } \\
\text { cerulein injection }\end{array}$ & $\begin{array}{l}\text { i.p. } 100 \mu \mathrm{g} / \mathrm{kg} / \mathrm{h} \text { cerulein, } \\
\text { every } 1 \mathrm{~h}, 6 \text { times }\end{array}$ & $\begin{array}{l}\downarrow \text { amylase, pancreatic MPO, TNF- } \alpha \text {, } \\
\text { IL- } 1 \beta, \text { IL- } 6 \text {, p38, Erk } \\
\uparrow \text { p53, cleaved caspase- } 3 \text {, apoptosis of } \\
\text { acinar cells }\end{array}$ & {$[119]$} \\
\hline SD rats & NP & $\begin{array}{l}\text { r.i.BPD } 5 \% \text { sodium } \\
\text { taurocholate. }\end{array}$ & $\begin{array}{l}\uparrow \text { survival rate, 6-keto-PGF1 alpha } \\
\downarrow \text { LPO, TXB2 }\end{array}$ & {$[120]$} \\
\hline \multicolumn{5}{|c|}{ Magnolol (lignan) found in Magnolia officinalis (Magnoliaceae) } \\
\hline RPA AR42J cells & $1.49 \mu \mathrm{g} / \mathrm{L}$ magnolol & cerulein & $\begin{array}{l}\uparrow \text { cell viability, apoptosis index; } \downarrow \\
\text { necrosis, LDH released from the cells, } \\
\text { ROS generation }\end{array}$ & {$[117]$} \\
\hline $\mathrm{BALB} / \mathrm{c}$ mice & $\begin{array}{l}\text { i.v. magnolol immediately } \\
\text { after the AP model was } \\
\text { reproduced, then at 9, 12, } 24 \\
\text { hours after modelling }\end{array}$ & i.p. cerulein hourly 7 times & $\begin{array}{l}\downarrow \text { amylase, pancreatic histopathologic } \\
\text { score } \\
\uparrow \text { ratio of myeloid/lymphoid dendritic } \\
\text { cells, ratio of IL-10/IFN- } \gamma\end{array}$ & {$[121]$} \\
\hline \multicolumn{5}{|c|}{ Naringin (flavone) found in citrus fruits and tomatoes } \\
\hline RPA AR42J cells & $53.7 \mu \mathrm{g} / \mathrm{L}$ naringin & cerulein & $\begin{array}{l}\uparrow \text { cell viability, apoptosis index } \\
\downarrow \text { necrosis, LDH released from the cells, } \\
\text { ROS generation }\end{array}$ & {$[117,118]$} \\
\hline \multicolumn{5}{|c|}{ Nordihydroguaiaretic acid (lignan) found in creosote bush, Larrea tridentata (Zygophyllaceae) } \\
\hline Swiss albino rats & $\begin{array}{l}30 \mathrm{mg} / \mathrm{kg} / \mathrm{h} \text {, orally, thrice at } \\
1 \mathrm{~h} \text { intervals }\end{array}$ & cerulein & $\begin{array}{l}\text { in plasma: } \\
\downarrow \text { amylase; } \downarrow \text { IGF- } 1 \\
\text { in pancreas: } \\
\downarrow \text { TBARS; } \uparrow \text { SOD; } \uparrow \text { GSH } \\
\downarrow \text { edema, damage score } \\
\uparrow \text { heat shock proteins } \\
\downarrow \text { MPO, NF- } \kappa \mathrm{B}, \text { TNF- } \alpha \text {, phosphorylated } \\
\text { p38 } \\
\uparrow \text { apoptotic cells number } \\
\text { modulates the posttranslational } \\
\text { modifications of histone } \mathrm{H} 3\end{array}$ & {$[122]$} \\
\hline \multicolumn{5}{|c|}{ Resveratrol (trans-3,5,4'-trihydroxystilbene) found in grapes, peanuts, soy, giant knotweed (Polygonum cuspidatum) beans } \\
\hline SD male rats & $\begin{array}{l}30 \mathrm{mg} / \mathrm{kg} \text { b.m. } \\
\text { intraperitoneally }\end{array}$ & $\begin{array}{l}\text { r.i.BPD } 4 \% \text { sodium } \\
\text { taurocholate }\end{array}$ & $\downarrow$ NF- $\kappa \mathrm{B}, \mathrm{TNF}-\alpha, \mathrm{IL}-8$ & {$[123]$} \\
\hline Male Wistar rats & $10 \mathrm{mg} / \mathrm{kg}$ i.p. $30 \mathrm{~min}$ pre-trt. & s.c. $3 \times 75 \mu \mathrm{g} / \mathrm{kg}$ CCK-8 & $\begin{array}{l}\downarrow \text { amylase, lipase, total pancreatic } \\
\text { histological damage, edema, acinar } \\
\text { vacuolization } \\
\uparrow \text { catalase }\end{array}$ & {$[124]$} \\
\hline Male SD rats & $\begin{array}{l}10 \mathrm{mg} / \mathrm{kg} \text {, injected through } \\
\text { penal vein } 5 \mathrm{~min} \text { post-trt. }\end{array}$ & $\begin{array}{l}\text { r.i.BPD } 4 \% \text { sodium } \\
\text { taurocholate }\end{array}$ & $\downarrow$ severity, NF- $\kappa \mathrm{B}$, iNOS in pMФs & [125] \\
\hline
\end{tabular}


TABLE 2: Continued.

\begin{tabular}{|c|c|c|c|c|}
\hline $\begin{array}{l}\text { Animals/cell type } \\
\text { used }\end{array}$ & $\begin{array}{l}\text { Dose, route of } \\
\text { administration, } \\
\text { duration of the study }\end{array}$ & AP model & Findings & Ref. \\
\hline Male SD rats & $\begin{array}{l}\text { i.v. } 20 \mathrm{mg} / \mathrm{kg}, 5 \mathrm{~min} \\
\text { post-trt. }\end{array}$ & $\begin{array}{l}\text { r.i.BPD } 4 \% \text { sodium } \\
\text { taurocholate }\end{array}$ & $\begin{array}{l}\uparrow \text { SOD } \\
\downarrow \text { MDA, serum TNF- } \alpha \text {, ICAM- } 1 \text { and } \\
\text { VCAM- } 1 \text { expression in the intestine }\end{array}$ & [126] \\
\hline Male SD rats & i.p. $10 \mathrm{mg} / \mathrm{kg}$ & $\begin{array}{l}\text { r.i.BPD } 4 \% \text { sodium } \\
\text { taurocholate }\end{array}$ & $\begin{array}{l}\uparrow \mathrm{Bcl}-2 \\
\downarrow \mathrm{Bax}, \text { caspases- } 3 \text { expressions in brain, } \\
\text { serum Zonula occludens } 1 \text { and Myelin } \\
\text { basic protein }\end{array}$ & [127] \\
\hline Male SD rats & $\begin{array}{l}\text { i.v. } 20 \mathrm{mg} / \mathrm{kg}, 10 \mathrm{~min} \text { after } \\
\text { SAP induction }\end{array}$ & $\begin{array}{l}\text { r.i.BPD } 4 \% \text { sodium } \\
\text { taurocholate }\end{array}$ & $\begin{array}{l}\downarrow \text { amylase, MDA, neutrophil infiltration } \\
\text { in pancreas } \\
\uparrow \text { SOD }\end{array}$ & [128] \\
\hline \multicolumn{5}{|c|}{ Dihydroresveratrol (trans-3,5,4'-trihydroxystilbene) found in grapes, peanuts, soy, giant knotweed (Polygonum cuspidatum) beans } \\
\hline SD rats & p.o. 10,20 , or $50 \mathrm{mg} / \mathrm{kg} / \mathrm{h}$ & $\begin{array}{l}\text { i.p. } \\
50 \mu \mathrm{g} / \mathrm{kg} / \mathrm{h} \text { cerulein, } 6 \text { times } \\
\text { and lipopolysaccharide } \\
7.5 \mathrm{mg} / \mathrm{kg}, 1 \text { time }\end{array}$ & $\begin{array}{l}\downarrow \text { amylase, lung injury, pulmonary levels } \\
\text { of TNF- } \alpha \text {, IL- } 1 \beta \text {, IL- } 6 \text {, NF- } \kappa \text { B }\end{array}$ & [129] \\
\hline SD rats & NP & $\begin{array}{l}\text { i.p. repetitive } \\
\text { administration, cerulein } \\
50 \mu \mathrm{g} / \mathrm{kg} / \mathrm{h} \text { followed LPS } \\
7.5 \mathrm{mg} / \mathrm{kg} 1 \text { time }\end{array}$ & $\downarrow$ amylase, lung injury, NF- $\kappa \mathrm{B}, \mathrm{MPO}$ & {$[130]$} \\
\hline \multicolumn{5}{|c|}{ Rhein (anthraquinone) found in Rheum spp. and in Senna spp. } \\
\hline RPA AR42J cells & $\begin{array}{l}479,119.8 \text {, and } 29.9 \mu \mathrm{g} / \mathrm{L} \\
\text { rhein }\end{array}$ & cerulein & $\begin{array}{l}\uparrow \text { apoptotic-to-necrotic cell ratio, } \mathrm{p} 53 \text {, } \\
\text { cytochrome } \mathrm{C} \text {, caspase- } 3, \mathrm{Bax} / \mathrm{Bcl}-2 \text { ratio } \\
\text { (dose dependent) }\end{array}$ & [53] \\
\hline male SD rats & $\begin{array}{l}10 \mathrm{mg} / \mathrm{kg} \text { rhein (conjugated } \\
\text { with HPDM) }\end{array}$ & $\begin{array}{l}\text { r.i.BPD } 3 \% \text { or } 5 \% \text { sodium } \\
\text { taurocholate }\end{array}$ & $\begin{array}{l}\downarrow \text { amylase, MPO, histological damage in } \\
\text { pancreas (inflammatory infiltrate, acinar } \\
\text { cell vacuolization \& necrosis), } \downarrow \text { IL-6, } \\
\text { TNF- } \alpha \text { (in serum, pancreas, lung) }\end{array}$ & {$[131]$} \\
\hline RPA AR42J cells & $479 \mu \mathrm{g} / \mathrm{L}$ rhein & cerulein & $\begin{array}{l}\uparrow \text { cell viability, apoptosis index; } \downarrow \\
\text { necrosis, LDH released from the cells, } \\
\text { ROS generation }\end{array}$ & [117] \\
\hline \multicolumn{5}{|c|}{ Rutin (rhamnoglucoside of quercetin) found in citrics, grapes, black tea, apple skin peels, amalaki (Emblica officinalis) } \\
\hline Swiss mice & $\begin{array}{l}\text { p.o. } 37.5,75 \text {, or } 150 \mathrm{mg} / \mathrm{kg} \text {, } \\
\text { after } 24,36,48 \text {, and } 60 \mathrm{~h} \text { of } \\
\text { AP induction }\end{array}$ & $\begin{array}{l}\text { i.p. } 8 \% \mathrm{~L} \text {-arginine } \\
\text { hydrochloride } 4 \mathrm{~g} / \mathrm{kg} \text { twice }\end{array}$ & $\begin{array}{l}\downarrow \text { pain, amylase, lipase, CRP, IL- } 6 \text {, } \\
\text { pancreatic MPO, edema index, necrosis, } \\
\text { MDA, 3-nitrotyrosine } \\
\uparrow \text { apoptosis, catalase, SOD }\end{array}$ & [132] \\
\hline $\begin{array}{l}\text { Male albino Wistar } \\
\text { rats }\end{array}$ & $\begin{array}{l}\text { p.o. } 100 \mathrm{mg} / \mathrm{kg} / \text { day from the } \\
\text { third week }\end{array}$ & $\begin{array}{l}\text { p.o. ethanol ( } 36 \% \text { of total } \\
\text { calories) } 5 \text { weeks, } \\
\text { i.p. cerulein } 20 \mu \mathrm{g} / \mathrm{kg} \text {, } \\
\text { thrice weekly, last } 3 \text { weeks }\end{array}$ & $\begin{array}{l}\downarrow \text { amylase, IL-1 } \beta \text {, IL-18, caspase-1, } \\
\text { ASC-NLRP3 } \\
\downarrow \text { MPO, TBARS, lipid hydroperoxides, } \\
\text { oxidative stress index } \\
\uparrow \text { GPx, SOD, CAT }\end{array}$ & [133] \\
\hline $\begin{array}{l}\text { Male albino Wistar } \\
\text { rats }\end{array}$ & $\begin{array}{l}\text { p.o. } 100 \mathrm{mg} \text { rutin } / \mathrm{kg} \text { from } \\
\text { 31st day till the } \\
\text { experimental period }\end{array}$ & $\begin{array}{l}\text { p.o. EtOH ( } 8-12 \mathrm{~g} / \mathrm{kg} / \text { day }) \\
\text { and HFD ( } 22 \% \text { fat) for } 90 \\
\text { days }\end{array}$ & $\begin{array}{l}\uparrow \text { mRNA expressionof CARD } \\
\downarrow \text { PYD, caspase- } 1 \text {, and TNF- } \alpha \\
\text { expressions, serum IL-18 and IL-6 }\end{array}$ & [134] \\
\hline
\end{tabular}

AngII: angiotensin II, AP: acute pancreatitis, AP-1: activator protein-1, AQP: aquaporin, CARD: caspase activation recruitment domain, d.f.: disease-free, DMSO: dimethyl sulfoxide, EAEEN: emodin-assisted early enteral nutrition, EEN: early enteral nutrition, ER: endoplasmic reticulum, f.c.i.v.i.: followed by continuous i.v. infusion of, fgl2: Fibrinogen-Like Protein 2, HPDM = N,N, $\mathrm{N}^{\prime}$-trimethyl- $\mathrm{N}^{\prime}$-(4-hydroxy-3-methylbenzyl)-1,3-propane diamine, gr.: groups, i.g.: intragastric, i.p.: intraperitoneal, i.v.: intravenous, i.v.b.: i.v. bolus, iNOS: inducible NO synthase, LPO: lipid peroxide, mCD14: membrane-bound cluster of differentiation 14 protein, MCP-1: monocyte chemoattractant protein-1, MDA: malondialdehyde, MIP-1 $\alpha$ : Macrophage inflammatory protein-1 $\alpha$, MPO: myeloperoxidase, NAP78: neutrophil-activating peptide 78, NO: nitric oxide, NP: not provided, PDTC: pyrrolidine dithiocarbamate, pMФs: peritoneal macrophages, PYD: pyrin domain of apoptosis-associated speck-like protein, r.i.BPD:retrograde injection into the bilio-pancreatic duct of, resp.: respectively, RPA: rat pancreatic acinar, s.c.: subcutaneous injection, SAP: severe AP, SD: Sprague-Dawley, SS: Sandostatin, TLR-4: Toll-like receptor 4, trt.: treatment, WA: Wistar-Albino. 
In the intestine, baicalin is hydrolysed to baicalein (the aglycone form) by $\beta$-glucuronidase, this conversion being required for absorption. Afterwards, baicalin is regenerated, by reglucuronidation, in the liver and intestine $[142,143]$.

4.2.1. In Vitro Studies. Studies performed on macrophagic cells demonstrated the anti-inflammatory and antioxidative effects of baicalin [140] which allows us to surmise a favourable effect in diseases characterized by systemic inflammation, such as AP, especially SAP.

Inflammation. Baicalin blocked the activation of the macrophages and lipopolysaccharide (LPS) induced synthesis of proinflammatory mediators [tumor necrosis factor $\alpha$ (TNF$\alpha$ ), endothelin-1 (ET-1), and thromboxane A2 (TXA2)] in RAW264.7 (macrophage-type) cells [140].

Oxidative/Nitrosative Stress. Baicalin staved off the augmentation in nitric oxide (NO) production and inducible nitric oxide synthase (iNOS) expression promoted by LPS and Interferon- $\gamma$ (IFN- $\gamma$ ) although it did not directly alter the activity of iNOS in RAW264.7 cells and pMФs. It also hindered the generation of reactive oxidative species (ROS) while increasing the intracellular level of superoxide dismutase (SOD) [140].

4.2.2. Animal Studies. Baicalin is able to take the edge off AP by a combination of dampened inflammation and oxidative stress and heightened apoptosis, an effect extending beyond the pancreas, to the other organs suffering under the systemic impact of AP, including the main tracts of the organism [digestive (liver, intestinal mucosa), respiratory (lung), and urinary (kidney)] and the lymphatic organs (spleen, thymus), which results in milder systemic disease and improved survival $[91,93,94]$.

Apoptosis. Baicalin promotes apoptosis (higher apoptosis index) in the pancreas (and also in the intestinal mucosa, lymph nodes, and spleen [93]) by activating caspase-3 [92] and by increasing the expression of Bax protein [91] not only in the pancreas but also in the lung and the intestinal mucosa (however it decreases it in spleen and lymph nodes) [93]. The apoptosis-inducing effect is at work also in the kidney (higher renal apoptotic indexes [91]), at least partially due to a decrease in the renal $\mathrm{Bcl}-2$ protein (although the level of Bax protein was not influenced) [91].

Necrosis. Baicalin diminishes amylase [44] and the pathological severity scores in pancreas and multiple other organs [94] and is at least as efficient as the currently used drugs (somatostatin/octreotide) in the treatment of AP [92].

Systemic Effects. Baicalin decreases the systemic severity of AP, as proven by lower endotoxinemia and improved survival $[91,93,94]$, while relieving the noxious effects on the kidney (where it preserves the normal histology and function: less severe renal pathological changes [91] and lower serum BUN [91]) and on other organs (it diminishes the pathological changes in multiple organs, including pancreas [44, 93], lung $[44,93]$, ileum, and lymph nodes [93]), which points to a putative ability to prevent the development of multiorgan dysfunction syndrome.

Inflammation. Baicalin decreases the inflammatory response, as indicated by lower markers of inflammation (IL-6 [44, 91], TNF- $\alpha[44,91-93])$ and of leukocyte recruitment (P-selectin, also involved in the aggregation of platelets) $[92,94]$ in rats with SAP. The pathways by which this effect is achieved pass through the downregulation of activators such as ET-1 $[91,94]$, PLA2 [91, 94], and TLR4 [44].

Oxidative/Nitrosative Stress. Baicalin decreases nitrosative stress, translated in lower levels of NOin rats with SAP [91, 94].

4.3. Crambene. Crambene is an unsaturated nitrile (1-cyano2-hydroxy-3-butene) derived from the breakdown of (epi)progoitrin glucosinolates found in many cruciferous plants (e.g., brussels sprouts) $[144,145]$. It was initially considered to be a selective pancreatotoxin (when administered at high doses, e.g., 100-200 mg/kg body weight/day), due to its capacity to induce changes consistent with apoptosis of pancreatic acinar cells, infiltration of pancreatic lobules by macrophages and acinar atrophy [146-148]. Unexpectedly, its toxicity was associated with a significant and persistent increase in the pancreatic glutathione (GSH) [149]. After more research was performed, its proapoptotic activity, when adequately manipulated by dosing and choosing the route of administration, turned to be a beneficial one, useful in the mitigation of acute pancreatitis in experimental studies. For instance, moderate oral doses $30-100 \mathrm{mg} / \mathrm{kg}$ increased pancreatic GSH levels without any pancreatotoxicity, while a single $50 \mathrm{mg} / \mathrm{kg}$ intravenous dose induced apoptosis, and $100 \mathrm{mg} / \mathrm{kg}$ caused severe pancreatotoxicity with necrosis in male Fischer 344 rats [150].

\subsubsection{In Vitro Studies}

Apoptosis. Treatment with $2 \mathrm{mM}$ crambene for $3 \mathrm{~h}$ induced apoptosis of isolated pancreatic acinar cells (confirmed by increase of caspase-3, caspase-8, and caspase- 9 activities), but not necrosis [151]. The phytocompound induced the collapse of mitochondrial membrane potential, followed by cytochrome $c$ release from the mitochondria, but neither TNF-alpha nor Fas ligand production by pancreatic acinar cells was changed. These results suggest the involvement of the intrinsic pathway of apoptosis (caspase-3, caspase-9) but do not exclude the simultaneous activation of extrinsic pathway (caspase-9) [151]. A coculture study revealed that CD36-positive macrophages might play an important role in phagocytosis of apoptotic acinar cells induced by $2 \mathrm{mM}$ crambene treatment, and phagocytosis seems to suppress the inflammatory response by increasing the release of antiinflammatory cytokine IL-10 [95].

\subsubsection{Animal Studies}

Apoptosis/Necrosis. Pretreatment with crambene induced apoptosis of pancreatic acinar cells and reduced the extent 
of cerulein-induced necrosis, edema, and hyperamylasemia [51]. The reduction of pancreatitis severity of pancreatitis is maximal when crambene was administered $12 \mathrm{hrs}$ before cerulein administration [51].

Inflammation. Another study revealed the mechanism through which apoptosis reduces the severity of acute pancreatitis: clearance of apoptotic acinar cells by CD36-positive macrophage induced the release of anti-inflammatory cytokines IL-10 and TGF $\beta 1$ [95].

4.4. Curcumin. Curcumin, a polyphenol (a curcuminoid, i.e., a linear diarylheptanoid), is the primary active constituent of turmeric (Curcuma longa) and other related species. It is poorly absorbed and the serum concentration declines rapidly, and therefore curcumin has limited systemic bioavailability $[152,153]$. Metabolism of curcumin involves biotransformation to dihydrocurcumin, tetrahydrocurcumin, and conversion into monoglucuronide and sulphate conjugates, which were detected in plasma of human subjects $[154,155]$. Taking into account the reduced absorption and rapid plasma clearance of curcumin, the scientists looked for solutions to improve its systemic bioavailability. Piperine was found to be an effective bioenhancer for curcumin by increasing its absorption and by inhibiting its hepatic and intestinal glucuronidation [156].

Clinical studies showed that, even at high doses (such as to $12 \mathrm{~g}$ daily for several months), curcumin therapy is devoid of side effects but for mild nausea and diarrhea $[153,157]$.

4.4.1. Animal Studies. There are a few studies confirming the beneficial effect of curcumin in AP by improving the balance between apoptosis and necrosis-inducing processes. Several animal models of pancreatitis have been used, both ethanol-dependent and non-ethanol-dependent, employed as inductor agents: arginine [96], sodium taurocholate [97, $98]$, cerulein $[99,100]$, and low-dose CCK-8 in previously ethanol-sensitized animals [100].

Apoptosis. Curcumin promotes apoptosis by activating caspase-3 $[96,98]$.

Necrosis. Curcumin reduces the pancreatic injury [99], as reflected by improved histopathologic scores [98] and lower levels/activities of pancreatic enzymes/amylase [96, 97, 99], lipase [96], and trypsin [98].

Systemic Effects. Curcumin also ameliorates the deleterious effects of pancreatitis on other organs and territories, as indicated by a decrease in transaminases levels [99], in the ascites volume [97], and in the airway hyperreactivity [101]. The latter was studied on a model of ischemia/reperfusioninduced pancreatic injury and the benefic effect of curcumin appears to be mediated by diminished expression of iNOS and TNF- $\alpha$ in the lung tissue [101].

Inflammation. The appeasing effect of curcumin on inflammation was pointed out by lower levels of the inflammatory cells (leukocytes [101]) and mediators such as cytokines (IL-6 [97, 98, 100], TNF- $\alpha$ [96-101]) and chemokines [98], including KC [100] and ENA-78 [96]. At least some of the explanation lies with the depressing effect on the activators of inflammation, specifically on the transcription factors (AP-1 [98], NF- $\kappa$ B [97, 98, 100], and NF- $\kappa$ B-p65 [99]), presumably by means of decreasing the activators of transcription factors (TLR4 [97]) and increasing the inhibitors of transcription factors (PPAR $\gamma[99])$.

Oxidative/Nitrosative Stress. Curcumin decreases the activity of the enzymes responsible for the oxidative aggression (MPO [96], iNOS [98, 100,101]), which translates into lower levels of the products of oxidative aggression $\left(\mathrm{HO}^{\bullet}[101]\right.$, $\mathrm{NO}[98,101]$, and protein carbonyls [96]).

\subsubsection{Human Clinical Studies}

Oxidative Stress. A single-blind, randomized, placebo-controlled study evaluated the effects of oral mixture of curcumin $(500 \mathrm{mg})$ with piperine $(5 \mathrm{mg})$ for 6 weeks on the clinical evolution and oxidative stress biomarkers in 20 patients with tropical pancreatitis, a type of chronic pancreatitis. The herbal formulation significantly reduced the erythrocyte malondialdehyde (MDA) level, a marker of lipid peroxidation, and increased the GSH level, without influencing the pain [158]. Whether curcumin would be beneficial or not in acute pancreatitis in humans remains to be investigated.

4.5. Embelin. Embelin is a benzoquinone derivative (2,5dihydroxy-3-undecyl-1,4-benzoquinone) identified in marlberry (Ardisia japonica, fam. Primulaceae) and various Embelia species such as Indian Embelia or vidanga (Embelia ribes Burm, fam. Primulaceae) and African Embelia (Embelia schimperi Vatke, fam. Primulaceae) [159-162].

\subsubsection{In Vitro Studies}

Apoptosis. Embelin is known as a cell-permeable, smallmolecular weight, and potent inhibitor of XIAP, due to its capacity to bind to the Baculovirus Inhibitor of apoptosis protein Repeat 3 (BIR3) domain in XIAP (the binding site for caspase-9) [160]. Thus, by preventing XIAP interaction with caspase-9, it allowed the activation of initiator caspase-9 in prostate cancer cells, which led to apoptosis. Embelin showed dose-dependent proapoptotic activity in pancreatic cancer cells also, and the effect was potentiated in combination with ellagic acid [163]. In another study, embelin inhibited XIAP expression in adenoviral vector encoding human X-linked inhibitor of apoptosis transduced human pancreatic islets [164]. The inhibition was even to lower level than the basal XIAP expression in normal islets. Pancreatic stellate cells represent another target of embelin $(10$ and $20 \mu \mathrm{M})$, their apoptosis being significantly increased by the phytocompound (by 3 and 6-fold, resp.) in vitro [163]. The proliferation rate of PSC was also increased, when compared to control [163].

Inflammation. Embelin inhibited the biosynthesis of eicosanoids in human polymorphonuclear leukocytes and monocytes in a potent, selective, noncompetitive, and reversible way, by directly targeting the human 5-lipoxygenase (5-LO) 
and microsomal prostaglandin (PG) $\mathrm{E}_{2}$ synthase (mPGES)-1 [165]. Therefore embelin was proposed as a novel chemotype for designing dual 5-LO/mPGES-1 inhibitors [165]. This inhibition did not correlate with the antioxidant properties of embelin. On the other way, human 12-LO, 15-LO, COX-1, COX-2, and cytosolic phospholipase $\mathrm{A}_{2}$ were not significantly affected by $10 \mu \mathrm{M}$ embelin [165].

\subsubsection{Animal Studies}

Apoptosis versus Necrosis. In mouse cerulein pancreatitis, subcutaneous injection of embelin $(20 \mathrm{mg} / \mathrm{kg})$ for 5 consecutive days significantly increased the activity level of caspase-9 (direct way), as well as caspase- 3 and caspase- 8 (indirect way), which were correlated with a 3 -fold increase in apoptosis [7]. These changes were associated with a decrease in necrosis and normalization of pancreatic histology, leading to the conclusion that embelin, in addition to its proapoptotic activity, displays antinecrotic activity, modulating the balance between apoptosis and necrosis in acute pancreatitis [7].

4.6. Emodin. Emodin is an anthraquinone derivative $(1,3,8$ trihydroxy-6-methyl-anthraquinone) found in rhubarb (Rheum spp., fam. Polygonaceae), buckthorn (Rhamnus spp., fam. Rhamnaceae), and Japanese knotweed (Fallopia japon$i c a$, fam. Polygonaceae) with proven anticancer and antiinflammatory effects [166]. Emodin has been used clinically for the treatment of AP for many years in China [167]. It is worth mentioning that a meta-analysis on the prospective randomized controlled studies using Chinese herbal medicine in nonbiliogenic severe AP (SAP) revealed rhubarb as the most often used (in 19 out of 22 studies) botanical drug [168].

\subsubsection{In Vitro Studies}

Apoptosis versus Necrosis. Emodin decreased the severity of AP (as demonstrated by lower amylase levels) by turning the acinar cells from the destructive pathway of necrosis to the sounder one leading to apoptosis, by means of reducing the calcium overload in the cytoplasm. The underlying mechanism seems to rely at least partially on the downregulation of the ER stress response in association with diminished expression of some of the involved proteins acting as ER stress transducers (as part of the unfolded protein response): Bip (ER chaperone immunoglobulin-binding protein), PERK (protein kinase-like ER kinase), ATF6 (activation transcription factor 6), and IRE1 (inositol-requiring protein 1) [113].

Inflammation. Emodin inhibited TNF- $\alpha$-induced NF- $\kappa \mathrm{B}$ activation and adhesion molecule expression (e.g., ICAM-1, VCAM-1, and ELAM-1) in human umbilical vein endothelial cells [169]. A study employing rat pMФs demonstrated the ability of emodin to block a purinergic receptor $\mathrm{P} 2 \mathrm{X}_{7} \mathrm{R}$ and thus to antagonize the ability of ATP to stimulate IL- $1 \beta$ release and to hinder phagocytosis [170]. These inflammationhampering effects explain the capacity of emodin to counteract the local and systemic effects of inflammation-generating diseases such as pancreatitis [167].
Oxidative Stress. A study done on rat pMФs highlighted emodin's suppressive action on ATP-triggered ROS production [170].

\subsubsection{Animal Studies}

Blood Flow. The onset of SAP is accompanied by a drop in the pancreatic blood flow which is at least partially the consequence of surging thromboxane B2 (TXB2) and plunging 6-keto- $\mathrm{PGF}_{1 \mathrm{a}}$ and $\mathrm{PGE}_{2}$ levels. Emodin reversed the ischemia typical for the early stages of SAP [102] while (and supposedly by means of) restoring the balance of vasoconstrictor/vasodilator eicosanoids [102, 103].

Necrosis. Emodin attenuated the pancreatic injury (lower amylase [44, 103, 108, 111, 114, 115] and lipase [103] and milder pathological changes/histological score [44, 103, 104, 108, 114, 167], including edema $[103,104,108,115]$, extravasation [104], vacuolization [108], hemorrhage $[103,115]$, and inflammatory infiltration and necrosis $[103,108,115])$ an effect augmented by concomitant early enteral nutrition (EEN) [115] or baicalin treatment [44]. Fastening the epithelial and endothelial barriers in the pancreas [104] and in the lungs [105] by increased expression of some of the proteins involved in the intercellular tight junctions (claudin-4 [105] and claudin-5 and occludin $[104,105])$ may contribute to antiedematous effect by diminishing paracellular permeability $[104,105]$.

Systemic Effects. On animal models of AP, emodin prevented multiorgan failure [167], reduced the general severity of the disease (diminished mortality [103, 114, 115] and endotoxin and lactate levels [115]) as well as the impact on other organs/territories \{peritoneum (less ascites [103, 114, 115]), liver (lower ALT and AST [115], improved histological score [167]), lungs (milder pathological changes of acute lung injury (ALI) $[44,104,111,167]$ ), and bowel (less damage [167] correlated with better intestinal transit and lower inflammatory activators and mediators (NF- $\kappa \mathrm{B}-\mathrm{p} 65$, TNF- $\alpha$, IL-1 $\beta$ ) [107], ameliorated intestinal flora [102], and improved survival and barrier function of intestinal mucosal cells [167] resulting in diminished passage of bacteria and endotoxin [112])\}, an effect boosted by the association with EEN [115] or with baicalein/baicalin in the case of ascites [114] and pulmonary injury [44]. The protective effect against ALI (translated in less pulmonary edema and inflammation) seems to be associated with the increased lung expression of aquaporins (AQP) 1 and 5 (AQP1 in the alveolar capillary endothelial cells and AQP5 in the alveolar type I and II cells), transmembrane proteins dedicated to water transport, whose decrease is strongly coupled with the development of ALI and pulmonary edema) [111].

Inflammation. Emodin decreased the level of inflammatory markers/mediators (TNF- $\alpha$ [44, 104, 108, 111, 114, 115], IL-6 $[44,104,108,114]$, IL-1 $\beta$ [108], and CRP $[114,115])$, an effect magnified by concurrent EEN [115] or baicalin/baicalein administration in the case of TNF- $\alpha[44,114]$. While exploring the possible pathways leading to this inflammation shut down, emodin has been proven to block the upregulation 
of TLR4 (even more so if associated with baicalin) [44], the activation of NF- $\kappa \mathrm{B}$ [108], and the expression of Pselectin [167]. Emodin has also been shown to hasten the resolution of inflammation by augmenting the expression of membrane-bound cluster of differentiation 14 protein and of intercellular adhesion molecule- 3 in $\mathrm{pM} \Phi$ s, which may promote the phagocytosis of apoptotic neutrophils, thereby encouraging inflammation fade-out [109].

Oxidative Stress. Emodin decreased the activity of hepatic and pancreatic MPO [115] and lowered MDA [108, 115] (an effect amplified by simultaneous EEN [115]) and increased the activity of SOD [108].

4.6.3. Human Clinical Studies. Although emodin pancreatoprotective activity was not evaluated as an isolated compound in human clinical studies, there are already available results on the effects of emodin containing medicinal plants in patients with pancreatitis.

Inflammation, Systemic Effects. In a study done on 126 patients with severe AP comparing rhubarb-assisted EEN with EEN alone and with parenteral nutrition (followed by enteral nutrition after a fortnight's delay), rhubarb-assisted EEN accelerated symptom resolution (abdominal pain, transit disorders, and fever) and recovery, decreased the severity of the disease (APACHE score) and of the systemic inflammation (white blood cell count, CRP, and IL-6), and reversed hepatic and renal injury [171].

In other studies, scientists have evaluated the effects of rhubarb administrated via different ways in subjects with SAP (e.g., acute hemorrhagic-necrotic pancreatitis) and found positive effects on the inflammatory markers [172, 173].

4.7. Flavanones Hesperidin and Naringin. Hesperidin is a flavanone glycoside (the aglycone is hesperetin) found primarily in citrus fruits [174] but also in the Chinese herbal formulation Da-Cheng-Qi decoction (DCDQ) [117], known especially for its capillary-wall-strengthening, antioxidant, antiinflammatory, anticarcinogenic, and antiallergic effects [174].

Naringin is a flavanone glycoside (the aglycone is naringenin) found primarily in tomatoes and various citrus fruits (especially in grapefruit, accounting for its bitter taste) with proven antioxidant, anti-inflammatory, antiapoptotic, and anticancer/chemopreventive properties, efficient in various models of cardiovascular, neurodegenerative, metabolic (diabetes mellitus), rheumatological (including osteoporosis), and oncological disorders [175].

\subsubsection{In Vitro Studies}

Apoptosis. Hesperidin is one of the compounds imparting healing proficiency in AP to the Chinese herbal formulation DCQD, augmenting the cellular survival and apoptosis-tonecrosis ratio and dampening the ROS generation [117].

\subsubsection{Animal Studies}

Inflammation and Oxidative/Nitrosative Stress. In an experiment done on an animal model with cerulein-provoked
AP, hesperidin reduced the severity of the disease (amylase level) and the intensity of the inflammatory process (edema, leukocyte infiltration) and of the ROS and NO generation (as measured by chemiluminescence using luminol and lucigenin) [116].

4.8. Lignans (Magnolol, Honokiol, and Nordihydroguaiaretic Acid). Nordihydroguaiaretic acid (NDGA) is a lignan extracted from creosote bush, Larrea tridentata (Zygophyllaceae), with documented efficiency in cancer prevention, diabetes, infections, and fertility regulation [176].

Magnolol and honokiol are lignans extracted from Magnolia officinalis (Magnoliaceae) able to fend off oxidative aggression, inflammation, cancer, and infections [177].

\subsubsection{Animal Studies}

Apoptosis. NDGA prevents acinar cells necrosis by enhancing Bcl-2 expression and promotes apoptosis (as confirmed by the increased number of apoptotic cells) by encouraging the phosphorylation of PP2A and the conversion of procaspase3 in caspase-3. NDGA seems to impact both sides of apoptosis/necrosis balance (furthering the first and encumbering the second) by its influence on the histone $\mathrm{H} 3$ modifications, resulting in altered expression of the genes involved in inflammatory/apoptotic cascade [122].

Magnolol [117] and honokiol [118] are two of the compounds in DCQD that have shown apoptosis-enhancing properties.

4.8.2. Necrosis/Injury. NDGA reduced the injury to the pancreatic tissue, with resultant milder edema (reflected by the increase in pancreas weight), histological damage, and plasma amylase surge [122].

NDGA augmented the expression of several heat shock proteins (DNAJ C15, HSPD1, and HSP 27), whose cytoprotective effect helped hindering the development of AP [122].

Magnolol reduced the $\mathrm{LDH}$ release from the pancreatic cells [117], the seric level of amylase, and the severity of pancreatic histopathologic alteration [121]. Honokiol also showed an ability to prevent pancreatic cells demise, reflected by lower LDH release [118].

Inflammation. NDGA attenuated the inflammation (and its consequence, necrosis) in the pancreatic tissue (lower levels of MPO, a marker of leukocyte infiltration, and of TNF- $\alpha$ ) by blocking the NF- $\kappa \mathrm{B}$ pathway (both decreased expression and activation by $\mathrm{p} 38$ phosphorylation) [122].

Magnolol quenches the inflammatory response in AP by reverting the imbalance between the two involved types of T helper (Th) cells, Th1 and Th2, a high Th1/Th2 promoting inflammation. The dendritic cell- (DC-) directed preferential differentiation of Th0 to Th1 (rather than to Th2) drives the inflammation in AP, but magnolol was able to increase the myeloid-to-lymphoid DC ratio, as well as the IL-10/IFN- $\gamma$ ratio, thereby switching the Th0 differentiation from the Th1 to Th2 and decreasing the Th1/Th2 ratio from the high proinflammatory levels typical for AP to some lower values more 
congenial with an appeased local and systemic inflammatory process [121].

Oxidative Stress. NDGA lowered the level of ROS (thiobarbituric acid reactive substrate) and strengthened the antioxidative mechanisms (increased SOD and GSH) [122].

4.9. Ligustrazine. Ligustrazine (tetramethylpyrazine) is a phytochemical isolated from Chinese herb chuānxiōng (Ligusticum wallichii, fam. Umbelliferae), used in Traditional Chinese Medicine (TCM) for more than 2000 years for invigorating blood and moving stagnant Qi or blood [178, 179]. Pancreatitis is not listed as a common indication of the plant, which is mainly used for gynaecological problems and headaches [179]. Nevertheless, the activation of blood circulation to dissipated blood stasis (one of the plant ethnopharmacological activities) is part of TCM strategy in pancreatitis therapy [180].

\subsubsection{Animal Studies}

Apoptosis versus Necrosis. Ligustrazine induced pancreatic acinar cell apoptosis in rats with SAP $[119,181]$, accelerating the process especially at an early stage of the disease [107]. Interestingly, although ligustrazine promoted apoptosis of acinar cells, it prevented cell apoptosis in the liver and kidney [181]. In another study, the phytocompound alleviated necrosis in rats with taurocholate-induced acute hemorrhagic necrotizing pancreatitis [120].

Inflammation. Ligustrazine reduced the levels of TNF- $\alpha$, IL$1 \beta$, IL-6, amylase, pancreatic MPO activity, and the degree of inflammatory cell infiltration in pancreas in rat models of AP $[119,182]$. This phytocompound seemed to alleviate the inflammatory complications of pancreatitis due to its capacity to reduce pathological changes in the lung, stomach, small intestine, kidney, and immune organs (thymus, spleen) [183186]. In one of these studies, ligustrazine was more effective than the other two phytochemicals (kakonein and Panax notoginsenosides) in alleviating the tissue damage in the small intestine and immune organs of SAP rats [183], but less effective in protecting pancreas than Panax notoginsenosides, although its action was more comprehensive [181].

Oxidative Stress. Ligustrazine exerted ROS scavenging properties and decreased the serum level of lipid peroxides in rats with acute hemorrhagic necrotizing pancreatitis [120].

4.10. Resveratrol. Resveratrol (trans-3,5,4'-trihydroxystilbene) found in various plants such as grapes, blueberries, peanuts, pistachios, soy, and giant knotweed (Polygonum cuspidatum) beans showed in various experimental models antiapoptotic, anti-inflammatory, and antioxidant features; therefore it is a potential candidate for pancreatitis treatment [187-190]. It is metabolised by colonic microbiota and converted into dihydroresveratrol, when orally administered [191]. Dihydroresveratrol is also produced by certain plant species (e.g., Orchidaceae family, Cannabis sativa) as a phytoalexin against stressors $[192,193]$.

\subsubsection{In Vitro Studies}

Apoptosis. Resveratrol is a blocker of pancreatic sulfonylurea receptors 1 SUR1/KIR6.2 ATP-sensitive K channels [194]. Sulfonylureas are reported to have an apoptotic activity in cultured human islets, through a mechanism involving blockade of $\mathrm{K}^{+}$ATP channels and depolarization-induced $\mathrm{Ca}^{2+}$ influx into the cell [195-197]. Correlated with this SUR1 ligand activity, the phytocompound displayed a proapoptotic effect, stronger than that of glibenclamide, in SUR1-expressing recombinant human embryonic kidney (HEK) cells, but also in native $\beta$-cells. Apoptotic parameters such as cell detachment, caspase-3, caspase-9, and caspase-12 activities and degree of nuclear fragmentation were enhanced after resveratrol treatment. The effect appeared after incubation with $100 \mu \mathrm{M}$ resveratrol for at least $24 \mathrm{~h}$ [194].

\subsubsection{Animal Studies}

Apoptosis versus Necrosis. Significant therapeutic effect of resveratrol was noticed in rats with AP by inducing apoptosis of pancreatic acinar cell as a consequence of upregulated FasL gene expression [198]. Resveratrol and dihydroresveratrol protect animals against pancreatitis complications (e.g., lung damage, intestinal barrier alteration, and brain and hepatic injury) $[126,127,130,199]$. Scientists claim that the mechanism responsible for this protective activity is based on the upregulation of antiapoptotic $\mathrm{Bcl}-2$ and downregulation of proapoptotic Bax and caspase-3 [127, 199]. It seems that resveratrol, like ligustrazine, has a selective bioactivity, being proapoptotic on acinar cells and antiapoptotic on other types of cells (e.g., hepatocytes).

Inflammation. Various scientists noticed that resveratrol and its metabolite (dihydroresveratrol) exerted a dose-dependent anti-inflammatory effect through $\mathrm{NF}-\kappa \mathrm{B}$ inhibition and decreased expression of TNF-alpha, IL- $1 \beta$, IL-6, and IL-8 in the pancreas, $\mathrm{pM} \Phi$ s, and other target organs (e.g., lungs), in various animal models of pancreatitis (e.g., sodium taurocholate, cerulein, and CCK-8-induced disease) [123-125, 129]. There are contradictory findings concerning the effects of resveratrol on the production of NO and NOS: activated endothelial NOS was found to be protective against ceruleininduced AP in mice, while inducible NOS exhibited proinflammatory effects in the same animal model [200-202].

Oxidative Stress. Resveratrol treatment induced an increase in the pancreatic SOD and a decrease of MDA within the first 6 hours of SAP induction in SD rats [128]. Dihydroresveratrol ameliorated the pancreatic oxidative damage by inhibiting the activities of NADPH oxidase and MPO and by restoring the glutathione pool [191].

4.10.3. Human Clinical Studies. A multicenter, prospective, randomized controlled clinical trial, registered on https:// www.clinicaltrials.org/ in 2016 (ClinicalTrials.gov Identifier: NCT02947932), is currently running in order to evaluate the efficacy of resveratrol in preventing post-Endoscopic Retrograde Cholangiopancreatography (ERCP) pancreatitis [203]. 
4.11. Rhein. Rhein is an anthraquinone derivative (endowed with a carboxyl group, hence alternative names of cassic or rheic acid) found in Rheum spp. (rhubarb) (like R. undulatum, $R$. palmatum, etc.) and in Senna spp. (S. reticulata, $S$. alexandrina, etc.). It is also a component of the Chinese herbal medicine Da-Cheng-Qi decoction [53].

\subsubsection{In Vitro Studies}

Apoptosis. Rhein promoted apoptosis in rat pancreatic acinar cells, dose-dependently enhancing the ratio of apoptotic-tonecrotic cells, as well as the level of p53, cytochrome $\mathrm{C}$, and caspase-3, and $\mathrm{Bax} / \mathrm{Bcl}-2$ ratio, which indicate the ability to channel the injured cells to die by mitochondrial apoptosis rather than by necrosis [53].

DCQD is of proven benefit in AP [204] and in its complications [205-208] - a search for the biochemical substrate thereof revealed four compounds (rhein, magnolol, hesperidin, and naringin) as champions, with rhein in the leading position. Pretreated with any of the four compounds, cultured pancreatic cells exposed to the deleterious effects of cerulein were healthier in life and more responsible in death (better viability, higher apoptosis, lower necrosis, and diminished ROS production). Among the four, however, rhein was the best not only in pharmacodynamic terms but also in pharmacokinetic characteristics: despite having the lowest concentration in DCQD, it reaches a much higher plasmatic level than the other three (the study was performed on a rat model of sodium taurocholate-induced AP) [117]. Some of the other components of DCDQ, particularly naringin (a flavanone) and honokiol (a lignan), seem to act synergistically with rhein, the combination of three being more efficient in spurring apoptosis compared to each of the individual components alone and compared to each combination of two components [118].

Apoptosis. Pretreatment with rhein protected the pancreatic cells from the cerulein-induce injury as proved by the drop in LDH release [117].

\subsubsection{Animal Studies}

Inflammation and Systemic Effects. The usefulness of rhein in the treatment of $\mathrm{AP}$ and its complications is severely limited by its failure to accumulate in the pancreas and other territories (such as lung), which may be nevertheless overcome by coupling it with a derivative of propane diamine which increments its affinity for pancreatic and lung tissue. Given to animals subjected to experimental AP, this conjugated compound (HPDM-rhein) reduced the severity of AP (lower amylase, milder injury to the acinar cells in terms of vacuolization and destruction), the neutrophilic inflammatory infiltrate (indicated by MPO and histological data), the local and systemic inflammatory reaction (lower levels of IL-6 and TNF- $\alpha$ in plasma, pancreas, and lung), the lung histological damage (alveolar wall thickening by edema and cellular infiltration), and the volume of ascites. Interestingly, many of these actions are also displayed by the unconjugated rhein, but at a much lower intensity, as not to differ significantly from the untreated controls, the only exception being IL- 6 at 3 hours [131].

4.12. Rutin. Rutin is a rhamnoglucoside of quercetin found in high amounts in several citrus fruits, grapes, black tea, apple skin peels, and amalaki fruits (Emblica officinalis). Rutin was found to be less absorbed than other quercetin glucosides (the bioavailability of rutin was $\sim 80 \%$ less than that of quercetin glucosides) [209, 210]. This low bioavailability is correlated with rutin conversion by gut microflora in the large intestine to various compounds (e.g., 3,4-dihydroxyphenylacetic acid, 3,4-dihydroxytoluene) [211, 212].

\subsubsection{In Vitro Studies}

Inflammation. 3,4-Dihydroxytoluene, a metabolite of rutin, exerted anti-inflammatory effects in LPS stimulated RAW 264.7 macrophages by deactivating NF- $\kappa$ B signalling [212]. Therefore this metabolite may be a potential adjuvant remedy against local and systemic inflammation in pancreatitis.

\subsubsection{Animal Studies}

Apoptosis versus Necrosis. In L-arginine induced AP model rutin decreased the pancreatic injury (less necrosis, edema and infiltration, and lower serum levels of the pancreatic enzymes) but also furthered apoptosis (enlarging the population of apoptotic cells in the pancreas) [132]. Paradoxically, rutin could also antagonize factors involved in other types of programmed cell death, such as pyroptosis. For instance, rutin treatment downregulated the expression of caspase-1 and pyrin domain (PYD) of the apoptosis-associated specklike protein (ASC), while it upregulated the expression of CARD (caspase activation recruitment domain (CARD) in male Wistar rats with cerulein-induced pancreatitis and fed on ethanol [133]. This dual effect of rutin on programmed cell death may be explained as being dependent on the type of mechanism involved and the degree of inflammation: proapoptotic activity during the early phase of pancreatitis and inflammation (first few days) [132], and antipyroptotic activity during the chronic stage of pancreatitis and inflammation (during the following weeks) [133].

Inflammation. Rutin tempered inflammation (lower CRP) and protected pancreas against inflammatory injury in both acute and chronic pancreatitis models via several mechanisms: decreased expression of cytokines (IL-1 $\beta$, IL-6, and TNF- $\alpha$ ) and decreased neutrophil infiltration (measured as MPO activity) [24, 132-134]. Rutin supplementation also preserved pancreatic microarchitecture, improved food consumption, and maintained net weight gain in rats with alcohol-induced and high-fat-induced chronic pancreatitis [24].

Oxidative Stress. In L-arginine induced AP model, beside alleviating abdominal hyperalgesia, rutin also diminished the oxidative stress (reflected in the ameliorated 3-nitrotyrosine level) and hindered lipid peroxidation (by decreasing MPO), while boosting SOD and catalase [132]. 


\section{Discussions}

5.1. Multitargeting: One Phytochemical-More Targets. Most of the phytochemicals are highly pleiotropic molecules with multiple targets and mechanisms of action (Table 3) [213]. All the phytochemicals selected, beyond their anti-inflammatory and antioxidant activity, displayed the potential to directly regulate the balance between apoptosis and necrosis of acinar cells, either by enhancing apoptosis or by decreasing necrosis. They multitarget the crossroads between apoptosis and necrosis pathways, which represent turnpoints in the progression of inflammatory changes in pancreatitis.

We must mention here certain recent efforts in application of the network pharmacology for selection of the best multitarget active phytochemicals as potential AP innovative drugs. Resveratrol was identified as the phytocompound with the highest number of potential targets (degree $=38$ ), followed by emodin (35), curcumin (32), honokiol (16), baicalin (15), and ligustrazine (13) [216].

5.2. Synergism: More Phytochemicals-One Target. We also highly value the studies on phytoceuticals synergy in AP [118], although they are unusually rare. Evaluation of traditional polyherbal formulation used for millenia in TCM, Ayurveda, or other ethnomedical systems may lead to the discovery of precious phytosynergisms with high therapeutic efficacy in AP.

5.3. Selective Bioactivity. A peculiar feature of certain phytochemicals is represented by their selective bioactivity (e.g., ligustrazine-proapoptotic on acinar cells, but antiapoptotic on liver and renal cells) [181], which may represent an advantage over the synthetic drugs.

5.4. Limitations of Our Hypothesis on Proapoptotic Dependent Efficacy of Phytoceuticals in AP. By contrast to these phytocompounds that promote apoptosis, there are others that block apoptosis and still favourably influence the evolution of AP (by attenuating inflammation, necrosis, and oxidative stress in the pancreatic tissue and by preventing its local and systemic complications): daphnetin (a coumarin from Dracaena marginata) [217], green tea polyphenols [218], and proanthocyanidins [214]. We could estimate that the rate and the degree of apoptosis, which directly influence the amount of proinflammatory DAMPs released, might explain this paradox: proapoptotic phytoceuticals exhibit benefits when apoptosis rate is extremely low, while antiapoptotic phytoceuticals display positive effects when apoptosis is exacerbated, and DAMPs phagocyting cells are overwhelmed. Nevertheless, it is desirable to perform comparative studies on the efficacy of pro- and antiapoptotic phytocompounds in AP, in order to reveal their hidden mechanisms of action and all their possible interferences with apoptosis and phagocytosis pathways in AP.

5.5. Research Challenges. Despite their advantages, the low bioavailability of certain phytoceuticals represents a serious limitation. Several mechanisms are claimed to be responsible for this pharmacokinetic behaviour: rapid sulphate conjugation by the intestine/liver (e.g., resveratrol) or low solubility (e.g., curcumin) [219, 220], but potential solutions were already proposed (e.g., use of bioenhancers, such as piperine) [156].

Future research challenges are represented by the evaluation of the phytochemical bioactivity in large-population clinical studies and identification of the potential side effects or interactions with synthetic drugs. It is also worth investigating the combined administration of several phytochemicals or of phytochemicals together with synthetic drugs to determine the optimal mixture for cost-effective therapies. Development of food items fortified with phytochemicals with clinically proven pancreatoprotective or pancreatoregenerative properties would contribute to the implementation of this theoretical knowledge into practice.

\section{Conclusions}

Activation of apoptosis via various mechanisms and/or inhibition of necrosis seems to represent the essential key for decreasing the severity of the acute pancreatitis. All the phytochemicals selected, belonging to such diverse classes as polyphenols (curcumin, resveratrol), flavonoids (baicalin, hesperidin, naringin, and rutin), lignans (honokiol, magnolol, and nordihydroguaiaretic acid), anthraquinones (emodin, rhein), sesquiterpene lactones (artemisinin), nitriles (crambene), and alkaloids (ligustrazine), target the balance between apoptosis and necrosis. Apart from tipping the apoptosis/necrosis balance, the phytochemicals displayed other specific protective activities: inhibition of inflammasome (e.g., rutin), suppression of neutrophil infiltration (e.g., ligustrazine, resveratrol), and antioxidant activity. These phytoceuticals may represent a promising complementary therapy for acute pancreatitis, having also few rare adverse reactions, and sometimes even better results than the standard treatment [92]. Nevertheless, there is a shortage of human evidence, and further studies are required to provide solid basis to justify their use in the treatment of this disease.

\section{Abbreviations}

Akt: Serine/threonine kinase

ALI: Acute lung injury

AP: Acute pancreatitis

AP-1: Activator protein 1

BIR: Baculovirus Inhibitor of apoptosis protein Repeat

CAM: Complementary and alternative medicines

CRP: $\quad$ C reactive protein

DAMP: The damage-associated molecular pattern

DC: Dendritic cell

DCQD: Chinese herbal formulation Da-Cheng-Qi decoction

EEN: Early enteral nutrition

ER: Endoplasmic reticulum

ET: Endothelin

FasL: $\quad$ Fas ligand (TNF superfamily, member 6)

GSH: Glutathione

GSP: Grape seed proanthocyanidins

GSSE: Grape seeds and skin extract 
TABLE 3: Potential mechanisms of action of phytocompounds in pancreatitis.

\begin{tabular}{|c|c|c|}
\hline & & Apoptosis \\
\hline \multirow{14}{*}{$\uparrow$ apoptosis } & $\begin{array}{l}\uparrow \text { apoptosis (index) of pancreatic } \\
\text { acinar cells }\end{array}$ & $\begin{array}{l}\text { Artemisinin [89], baicalin }[92,93] \text {, crambene }[51,95] \text {, embelin }[7], \text { emodin } \\
{[113], \text { hesperidin }[117,118] \text {, ligustrazine }[119] \text {, magnolol }[117] \text {, naringin }} \\
{[117,118] \text {, nordihydroguaiaretic acid }[122] \text {, rhein }[53,117] \text {, rutin }[132]}\end{array}$ \\
\hline & $\uparrow$ Bax protein & Baicalin $[91,93]$ \\
\hline & $\uparrow$ caspase- 3 & $\begin{array}{l}\text { Artemisinin [89], baicalin [92], crambene [51], curcumin [96, 98], embelin } \\
\text { [7], ligustrazine [119], rhein [53] }\end{array}$ \\
\hline & Cytochrome C & Rhein $[53]$ \\
\hline & $\uparrow \mathrm{p} 53$ & Ligustrazine [119], rhein [53] \\
\hline & $\downarrow \mathrm{Bcl}-2$ protein renal & Baicalin [91] \\
\hline & $\downarrow$ p38 & Ligustrazine [119] \\
\hline & $\uparrow$ Bax protein & Baicalin $[91,93]$ \\
\hline & $\uparrow \mathrm{Bax} / \mathrm{Bcl}-2$ ratio & Rhein [53] \\
\hline & $\uparrow$ caspase- $8,-9$ & Crambene [51], embelin [7] \\
\hline & $\uparrow$ renal apoptotic indexes & Baicalin [91] \\
\hline & $\begin{array}{l}\downarrow \text { calcium overload in the } \\
\text { cytoplasm }\end{array}$ & Emodin [113] \\
\hline & $\downarrow$ ER stress transducers & Emodin [113] \\
\hline & $\begin{array}{l}\text { Modulates the posttranslational } \\
\text { modifications of histone } \mathrm{H} 3\end{array}$ & Nordihydroguaiaretic acid [122] \\
\hline \multirow{8}{*}{$\downarrow$ apoptosis } & $\uparrow \mathrm{Bcl}-2$ & Resveratrol [127] \\
\hline & $\uparrow$ mRNA expression of CARD & Rutin [134] \\
\hline & $\begin{array}{l}\downarrow \text { apoptosis of intestinal mucosa } \\
\text { cells }\end{array}$ & Emodin [112] \\
\hline & $\downarrow \mathrm{Bax}$ & Resveratrol [127] \\
\hline & $\downarrow$ caspase- 1 & Rutin $[133,134]$ \\
\hline & $\downarrow$ caspase- $3,-8,-9,-12$ & Grape seed proanthocyanidins [214] \\
\hline & $\downarrow$ caspases- 3 expressions in brain & Resveratrol [127] \\
\hline & $\downarrow$ PYD & Rutin [134] \\
\hline \multicolumn{3}{|r|}{ Inflammation } \\
\hline Inflammation markers & $\downarrow \mathrm{CRP}$ & Emodin [115], rutin [132] \\
\hline \multirow{11}{*}{ Inflammation activators } & $\downarrow$ AP-1 & Curcumin [98], curcumin [100] \\
\hline & $\downarrow$ ASC-NLRP3 & Rutin [133] \\
\hline & $\downarrow$ Erk & Ligustrazine [119] \\
\hline & $\downarrow \mathrm{I} \kappa \mathrm{B}$ degradation & Curcumin [100] \\
\hline & $\downarrow \mathrm{MCP}-1$ & Crambene [95] \\
\hline & $\downarrow$ MIP-1 $\alpha$ protein & Artemisinin [89] \\
\hline & $\downarrow$ NAP78 & Curcumin [96] \\
\hline & $\downarrow N F-\kappa B$ (activation) & $\begin{array}{l}\text { Artemisinin }[89] \text {, curcumin }[97-100] \text {, dihydroresveratrol }[129,130] \text {, emodin } \\
{[107,108] \text {, grape seed proanthocyanidins }[214] \text {, nordihydroguaiaretic acid }} \\
{[122] \text {, resveratrol }[123,125]}\end{array}$ \\
\hline & $\downarrow$ phosphorylated p38 & Nordihydroguaiaretic acid [122] \\
\hline & $\downarrow \mathrm{PKC} \alpha$ & Breviscapine [215] \\
\hline & $\downarrow$ TLR4 expression in pancreas & Curcumin [97] emodin + baicalin [44] \\
\hline \multirow{4}{*}{ Inflammation inhibitors } & $\uparrow \mathrm{Nrf2}$ & Grape seed proanthocyanidins [214] \\
\hline & $\uparrow \operatorname{PPAR} \gamma$ & Curcumin [99] \\
\hline & $\uparrow$ IL-10 & Crambene [95] \\
\hline & $\begin{array}{l}\uparrow \text { ratio IL-10/ IFN- } \gamma \text { \& ratio of } \\
\text { myeloid/lymphoid dendritic cells }\end{array}$ & Magnolol [121] \\
\hline
\end{tabular}


TABle 3: Continued.

\begin{tabular}{|c|c|c|}
\hline $\begin{array}{l}\text { Promoting phagocytosis } \\
\text { of apoptotic neutrophils }\end{array}$ & $\begin{array}{l}\uparrow \text { ICAM-3 and } \mathrm{mCD} 14 \\
\text { expression in } \mathrm{pM} \Phi \mathrm{s}\end{array}$ & Emodin $[109,110]$ \\
\hline \multirow{13}{*}{ Inflammation mediators } & $\downarrow$ chemokine & Curcumin $[98,100]$ \\
\hline & $\downarrow$ cytokines & Rutin [133] \\
\hline & $\downarrow$ ET-1 & Baicalin [91], baicalin [94] \\
\hline & $\begin{array}{l}\downarrow \text { ICAM- } 1 \text { and VCAM-1 } \\
\text { expression in the intestine }\end{array}$ & Resveratrol [126] \\
\hline & $\downarrow$ IFN- $\gamma$ & Grape seed proanthocyanidins [214] \\
\hline & $\downarrow$ IL-18 & Rutin $[133,134]$ \\
\hline & $\downarrow$ IL-1 $\beta$ & $\begin{array}{l}\text { Artemisinin [89], crambene [95], dihydroresveratrol [129], emodin }[107,108] \text {, } \\
\text { grape seed proanthocyanidins [214], ligustrazine [119], rutin [133] }\end{array}$ \\
\hline & $\downarrow$ IL-6 & $\begin{array}{l}\text { Baicalin [91], curcumin }[98,100] \text {, dihydroresveratrol [129], emodin } \\
{[104,105,108] \text {, emodin + baicalin/baicalein }[44,114] \text {, ligustrazine [119], rhein }} \\
{[131] \text {, rutin }[132,134]}\end{array}$ \\
\hline & $\downarrow$ IL-8 & Resveratrol $[123]$ \\
\hline & $\downarrow$ PLA2 & Baicalin $[91,94]$ \\
\hline & $\downarrow$ P-selectin & Baicalin $[92,94]$ \\
\hline & $\downarrow$ TNF- $\alpha$ & $\begin{array}{l}\text { Baicalin [91-93], crambene [95], curcumin [96-101], emodin } \\
{[104,105,107,108,111,115] \text {, emodin + baicalin/baicalein }[44,114] \text {, grape seed }} \\
\text { proanthocyanidins }[214] \text {, ligustrazine }[119] \text {, nordihydroguaiaretic acid }[122] \text {, } \\
\text { resveratrol }[123,126], \text { rhein }[131] \text {, rutin }[134]\end{array}$ \\
\hline & $\downarrow$ WBC count & Curcumin [101], rutin [134] \\
\hline & & Nitrosative stress \\
\hline \multirow{2}{*}{ Nitrosative enzymes } & $\downarrow$ iNOS & Curcumin $[98,100]$ \\
\hline & $\downarrow$ iNOS in $\mathrm{pM} \Phi \mathrm{s}$ & Resveratrol [125] \\
\hline \multirow{2}{*}{ Nitrosation products } & $\downarrow \mathrm{NO}$ & Baicalin $[91,94]$, curcumin $[98,101]$, Hesperidin $[116]$ \\
\hline & $\downarrow 3$-nitrotyrosine & Rutin [132] \\
\hline & & Oxidative stress \\
\hline \multirow[t]{2}{*}{ Oxidative enzymes } & $\downarrow \mathrm{MPO}$ & $\begin{array}{l}\text { Artemisinin [89], curcumin [96], dihydroresveratrol [130], emodin }[105,115] \text {, } \\
\text { ligustrazine [119], nordihydroguaiaretic acid [122], rhein [131], rutin }[132,133]\end{array}$ \\
\hline & $\downarrow$ MPO hepatic & Emodin [115] \\
\hline \multirow{5}{*}{$\begin{array}{l}\text { Protective antioxidant } \\
\text { enyzmes/mechanisms }\end{array}$} & $\uparrow \mathrm{GPx}$ & Rutin [133] \\
\hline & $\uparrow$ catalase & Resveratrol $[124]$, rutin $[132,133]$ \\
\hline & $\uparrow \mathrm{HO}-1$ & Grape seed proanthocyanidins [214] \\
\hline & $\uparrow \mathrm{SOD}$ & $\begin{array}{l}\text { Emodin }[108], \text { nordihydroguaiaretic acid }[122] \text {, resveratrol }[126,128], \text { rutin } \\
{[132,133]}\end{array}$ \\
\hline & $\uparrow \mathrm{GSH}$ & Nordihydroguaiaretic acid [122] \\
\hline \multirow{10}{*}{ Oxidation products } & $\downarrow \mathrm{HO}^{\circ}$ & Curcumin [101] \\
\hline & $\downarrow$ lipid hydroperoxides & Rutin [133] \\
\hline & $\downarrow$ LPO & ligustrazine [120] \\
\hline & $\downarrow \mathrm{MDA}$ & Emodin $[108,115]$, resveratrol $[126,128]$, rutin $[132]$ \\
\hline & $\downarrow$ oxidative stress index & Rutin [133] \\
\hline & $\downarrow$ protein carbonyls & Curcumin [96] \\
\hline & $\downarrow$ ROS generation & Hesperidin [116, 117], magnolol [117], naringin [117, 118], rhein [117] \\
\hline & $\downarrow$ TBARS & Nordihydroguaiaretic acid [122], rutin [133] \\
\hline & $\downarrow$ pancreatic fgl-2 & Curcumin [96] \\
\hline & $\begin{array}{l}\downarrow \text { Pancreatic inflammation } \\
\text { (pancreatic release of IL-1 } \beta \text { and } \\
\text { IL-6) }\end{array}$ & Artemisinin [90] \\
\hline
\end{tabular}


TABLE 3: Continued.

\begin{tabular}{|c|c|c|}
\hline \multicolumn{2}{|c|}{ Protection against injury $\uparrow$ heat shock proteins } & \multirow{2}{*}{ Nordihydroguaiaretic acid [122] } \\
\hline \multirow{5}{*}{ Blood flow } & $\uparrow$ pancreatic blood flow & \\
\hline & $\uparrow$ 6-keto-PGF1 $\alpha$ & Emodin $[102,103]$, ligustrazine $[120]$ \\
\hline & $\uparrow$ PGE2 & Emodin $[102,103]$ \\
\hline & $\downarrow$ AngII & Emodin $[115]$ \\
\hline & $\downarrow$ TXB2 & Emodin [102], emodin [103], ligustrazine [120] \\
\hline \multirow[b]{2}{*}{ Pancreatic fibrosis } & Pancreatic fibrosis $€ \uparrow$ TGF- $\beta 1$ & Crambene [95], emodin [106] \\
\hline & $\begin{array}{l}\text { Pancreatic fibrosis } € \downarrow \text { collagen, } \\
\text { fibronectin, laminin, pancreatic } \\
\text { fibrosis }\end{array}$ & Emodin $[106]$ \\
\hline \multicolumn{3}{|c|}{ e } \\
\hline \multirow{6}{*}{$\begin{array}{l}\text { Lung inflammatory } \\
\text { activators }\end{array}$} & $\downarrow N F-\kappa B$ & Dihydroresveratrol [129] \\
\hline & $\downarrow$ TLR4 expression & Emodin + baicalin/baicalein [44] \\
\hline & $\downarrow$ TNF- $\alpha$ & Curcumin $[101]$ \\
\hline & $\downarrow \mathrm{IL}-1 \beta, \mathrm{IL}-6$ & Dihydroresveratrol [129] \\
\hline & $\downarrow$ pulmonary & Dihydroresveratrol [129] \\
\hline & $\downarrow$ TNF- $\alpha$ lung & Curcumin [101], dihydroresveratrol [129], rhein [131] \\
\hline Lung nitrosative stress & $\downarrow$ iNOS lung & Curcumin [101] \\
\hline \multirow{5}{*}{ Lung function } & $\downarrow$ lung hyperreactivity & Curcumin [101] \\
\hline & $\uparrow$ claudin- 4 & Emodin [105] \\
\hline & $\uparrow$ claudin-5 & Emodin $[104,105]$ \\
\hline & $\uparrow$ occludin & Emodin $[104,105]$ \\
\hline & $\uparrow \mathrm{AQP1}$ and AQP5 in lung & Emodin $[111]$ \\
\hline \multicolumn{3}{|r|}{ Bowel } \\
\hline \multirow{2}{*}{ Bowel injury } & $\begin{array}{l}\downarrow \text { bacteria and endotoxin } \\
\text { translocation }\end{array}$ & Emodin $[112]$ \\
\hline & $\begin{array}{l}\downarrow \text { ICAM-1 and VCAM-1 } \\
\text { expression in the intestine }\end{array}$ & Resveratrol [126] \\
\hline
\end{tabular}

HO: Hemoxygenase

IAP: Inhibitor of apoptosis proteins

IFN- $\gamma$ : Interferon- $\gamma$

IL: Interleukine

iNOS: Inducible nitric oxide synthase

LPS: Lipopolysaccharide

MCP-1: Monocyte Chemoattractant Protein 1

MIP-1 $\alpha$ : Macrophage inflammatory protein- $1 \alpha$

MPO: Myeloperoxidase

NDGA: Nordihydroguaiaretic acid

NF- $\kappa$ B: Nuclear factor kappa-light-chain-enhancer of activated B cells

NO: $\quad$ Nitric oxide

NOS: Nitric oxide synthase

PAF: Platelet activating factor

PG: $\quad$ Prostaglandin

PI3K: Phosphatidylinositol 3-kinase

PIDD: p53-induced protein with death domain

PLA2: Phospholipase A2

PLC $\beta$ : Phospholipase $\mathrm{C} \beta$

pMФs: Peritoneal macrophages

PSC: Pancreatic stellate cells
RAIDD: RIP-associated ICH-1/CED-3 homogenous protein with death domain

RANTES: Regulated on Activation, Normal T Cell Expressed and Secreted

RIPK: Receptor-interacting protein kinase

ROS: $\quad$ Reactive oxidative species

SAP: $\quad$ Severe acute pancreatitis

TGF- $\beta$ : Transforming growth factor- $\beta$

Th: Thelper

TLR4: Toll-like receptor 4

TNF: Tumor necrosis factor

TXA2: Thromboxane A2

TXB2: Thromboxane B2.

\section{Conflicts of Interest}

The authors declare no conflicts of interest.

\section{Authors' Contributions}

Laura Gaman and Dorin Dragos equally contributed to this work as first authors. All the authors have contributed to all of the following steps: (1) the conception of the study, 
search of literature, and acquisition of data; (2) analysis and interpretation of data retrieved from the literature; and (3) writing the draft of the manuscript and revision of the article. All authors have read and approved the final manuscript.

\section{References}

[1] O. Windisch, T. Raffoul, C. Hansen et al., "Acute pancreatitis: new aspects for the management," Revue Médicale Suisse, vol. 13, no. 567, pp. 1240-1246, 2017.

[2] Y. C. Chan and P. S. Leung, "Acute pancreatitis: Animal models and recent advances in basic research," Pancreas, vol. 34, no. 1, pp. 1-14, 2007.

[3] J.-M. Park, S. Lee, M. K. Chung et al., "Antioxidative phytoceuticals to ameliorate pancreatitis in animal models: An answer from nature," World Journal of Gastroenterology, vol. 20, no. 44, pp. 16570-16581, 2014.

[4] C. Boumitri, E. Brown, and M. Kahaleh, "Necrotizing pancreatitis: Current management and therapies," Clinical Endoscopy, vol. 50, no. 4, pp. 357-365, 2017.

[5] R. Mofidi, M. D. Duff, S. J. Wigmore, K. K. Madhavan, O. J. Garden, and R. W. Parks, "Association between early systemic inflammatory response, severity of multiorgan dysfunction and death in acute pancreatitis," British Journal of Surgery, vol. 93, no. 6, pp. 738-744, 2006.

[6] C. D. Johnson and M. Abu-Hilal, "Persistent organ failure during the first week as a marker of fatal outcome in acute pancreatitis," Gut, vol. 53, no. 9, pp. 1340-1344, 2004.

[7] O. A. Mareninova, K. Sung, P. Hong et al., "Cell death in pancreatitis: caspases protect from necrotizing pancreatitis," The Journal of Biological Chemistry, vol. 281, no. 6, pp. 3370-3381, 2006.

[8] F. S. Gorelick, I. M. Modlin, S. D. Leach, R. Carangelo, and M. Katz, "Intracellular proteolysis of pancreatic zymogens," Yale Journal of Biology and Medicine, vol. 65, no. 5, pp. 407-440, 1992.

[9] E. C. Thrower, A. P. E. Diaz De Villalvilla, T. R. Kolodecik, and F. S. Gorelick, "Zymogen activation in a reconstituted pancreatic acinar cell system," American Journal of PhysiologyGastrointestinal and Liver Physiology, vol. 290, no. 5, pp. G894G902, 2006.

[10] G. C. Nikou, T. P. Arnaoutis, E. J. Giamarellos-Bourboulis et al., "The significance of the dosage adjustment of octreotide in the treatment of acute pancreatitis of moderate severity," HepatoGastroenterology, vol. 48, no. 42, pp. 1754-1757, 2001.

[11] K. Krishnan, "Nutritional management of acute pancreatitis," Current Opinion in Gastroenterology, vol. 33, no. 2, pp. 102-106, 2017.

[12] M. J. Dimagno, "Clinical update on fluid therapy and nutritional support in acute pancreatitis," Pancreatology, vol. 15, no. 6, pp. 583-588, 2015.

[13] X. Zhang, J. Zhang, and P. Yang, "Research status of the mechanism and treatment for acute pancreatitis complicated with hepatic injury," Journal of Nanjing Medical University, vol. 22, no. 4, pp. 199-204, 2008.

[14] A. G. Harris, "Somatostatin and somatostatin analogues: pharmacokinetics and pharmacodynamic effects," Gut, vol. 35, no. 3, supplement, pp. S1-S4, 1994.

[15] J. A. Greenberg, J. Hsu, M. Bawazeer et al., "Clinical practice guideline: Management of acute pancreatitis," Canadian Journal of Surgery, vol. 59, no. 2, pp. 128-140, 2016.

[16] H. J. Aho, R. A. Ahola, A. M. Tolvanen, and T. J. Nevalainen, "Experimental pancreatitis in the rat. Changes in pulmonary phospholipids during sodium taurocholate-induced acute pancreatitis," Research in Experimental Medicine, vol. 182, no. 1, pp. 79-84, 1983.

[17] H. Kim, "Cerulein pancreatitis: oxidative stress, inflammation, and apoptosis," Gut and Liver, vol. 2, no. 2, pp. 74-80, 2008.

[18] J. J. Hyun and H. S. Lee, "Experimental models of pancreatitis," Clinical Endoscopy, vol. 47, no. 3, pp. 212-216, 2014.

[19] M. Yamamoto, M. Otani, and M. Otsuki, "A new model of chronic pancreatitis in rats," American Journal of PhysiologyGastrointestinal and Liver Physiology, vol. 291, no. 4, pp. G700G708, 2006.

[20] S. Tani, H. Itoh, Y. Okabayashi et al., "New model of acute necrotizing pancreatitis induced by excessive doses of arginine in rats," Digestive Diseases and Sciences, vol. 35, no. 3, pp. 367374, 1990.

[21] C. Weaver, A. E. Bishop, and J. M. Polak, "Pancreatic changes elicited by chronic administration of excess L-arginine," Experimental and Molecular Pathology, vol. 60, no. 2, pp. 71-87, 1994.

[22] A. Vonlaufen, Z. Xu, B. Daniel et al., "Bacterial endotoxin: a trigger factor for alcoholic pancreatitis? evidence from a novel, physiologically relevant animal model," Gastroenterology, vol. 133, no. 4, pp. 1293-1303, 2007.

[23] B. A. Neuschwander-Tetri, K. R. Bridle, L. D. Wells, M. Marcu, and G. A. Ramm, "Repetitive acute pancreatic injury in the mouse induces procollagen $\alpha 1$ (I) expression colocalized to pancreatic stellate cells," Laboratory Investigation, vol. 80, no. 2, pp. 143-150, 2000.

[24] R. Aruna, A. Geetha, and P. Suguna, "Rutin modulates ethanol and high fat diet - induced inflammatory changes in pancreas-a dose response study in rats," International Journal of Pharmacy and Pharmaceutical Sciences, vol. 4, no. 4, pp. 409414, 2012.

[25] G. Sparmann, J. Merkord, A. Jaschke et al., "Pancreatic fibrosis in experimental pancreatitis induced by dibutyltin dichloride," Gastroenterology, vol. 112, no. 5, pp. 1664-1672, 1997.

[26] K. W. Simpson, N. Beechey-Newman, C. R. Lamb et al., "Cholecystokinin-8 induces edematous pancreatitis in dogs associated with short burst of trypsinogen activation," Digestive Diseases and Sciences, vol. 40, no. 10, pp. 2152-2161, 1995.

[27] J. Norman, "The role of cytokines in the pathogenesis of acute pancreatitis," The American Journal of Surgery, vol. 175, no. 1, pp. 76-83, 1998.

[28] W. Denham, J. Yang, and J. Norman, "Evidence for an unknown component of pancreatic ascites that induces adult respiratory distress syndrome through an interleukin-1 and tumor necrosis factor-dependent mechanism," Surgery, vol. 122, no. 2, pp. 295302, 1997.

[29] J. Yang, C. Murphy, W. Denham et al., "Evidence of a central role for p38 map kinase induction of tumor necrosis factor $\alpha$ in pancreatitis-associated pulmonary injury," Surgery, vol. 126, no. 2, pp. 216-222, 2017.

[30] I. Samuel, A. Zaheer, and R. A. Fisher, "In vitro evidence for role of ERK, p38, and JNK in exocrine pancreatic cytokine production," Journal of Gastrointestinal Surgery, vol. 10, no. 10, pp. 1376-1383, 2006.

[31] C. Schafer and J. A. Williams, "Stress kinases and heat shock proteins in the pancreas: possible roles in normal function and disease," Journal of Gastroenterology, vol. 35, no. 1, pp. 1-9, 2000.

[32] F. Fleischer, R. Dabew, B. Göke, and A. C. C. Wagner, "Stress kinase inhibition modulates acute experimental pancreatitis," 
World Journal of Gastroenterology, vol. 7, no. 2, pp. 259-265, 2001.

[33] S. A. Pendharkar, R. G. Singh, and M. S. Petrov, "Cross-talk between innate cytokines and the pancreatic polypeptide family in acute pancreatitis," Cytokine, vol. 90, pp. 161-168, 2017.

[34] D. Gordon, "Substance P: Pivotal roles in pain and pancreatitis," Gastroenterology, vol. 115, no. 1, p. 4, 1998.

[35] H. Liu, W. Li, X. Wang, J. Li, and W. Yu, "Early gut mucosal dysfunction in patients with acute pancreatitis," Pancreas, vol. 36, no. 2, pp. 192-196, 2008.

[36] L.-R. Liu and S.-H. Xia, "Role of patelet-activating factor in pathogenesis of acute pancreatitis," World Journal of Gastroenterology, vol. 12, no. 4, pp. 539-545, 2006.

[37] R.-L. Ji, S.-H. Xia, Y. Di, and W. Xu, "Mechanism and dose-effect of Ginkgolide B on severe acute pancreatitis of rats," World Journal of Gastroenterology, vol. 17, no. 17, pp. 2241-2247, 2011.

[38] B. D. Flickinger and M. S. Olson, "Localization of the plateletactivating factor receptor to rat pancreatic microvascular endothelial cells," The American Journal of Pathology, vol. 154, no. 5, pp. 1353-1358, 1999.

[39] E. Andréasson, K. Önnheim, and H. Forsman, “The subcellular localization of the receptor for platelet-activating factor in neutrophils affects signaling and activation characteristics," Clinical and Developmental Immunology, vol. 2013, Article ID 456407, 11 pages, 2013.

[40] M. Bhatia, "Acute pancreatitis as a model of SIRS," Frontiers in Bioscience, vol. 14, no. 6, pp. 2042-2050, 2009.

[41] J. A. Mitchell, B. Ryffel, V. F. J. Quesniaux, N. Cartwright, and M. Paul-Clark, "Role of pattern-recognition receptors in cardiovascular health and disease," Biochemical Society Transactions, vol. 35, no. 6, pp. 1449-1452, 2007.

[42] G. B. Johnson, G. J. Brunn, and J. L. Platt, "Cutting edge: an endogenous pathway to systemic inflammatory response syndrome (SIRS)-like reactions through Toll-like receptor-4," The Journal of Immunology, vol. 172, no. 1, pp. 20-24, 2004.

[43] A. Hietaranta, H. Mustonen, P. Puolakkainen, R. Haapiainen, and E. Kemppainen, "Proinflammatory effects of pancreatic elastase are mediated through TLR4 and NF- $\kappa \mathrm{B}$," Biochemical and Biophysical Research Communications, vol. 323, no. 1, pp. 192-196, 2004.

[44] Z. Li, X. Xia, S. Zhang, A. Zhang, W. Bo, and R. Zhou, "Up-regulation of Toll-like receptor 4 was suppressed by emodin and baicalin in the setting of acute pancreatitis," Biomedicine \& Pharmacotherapy, vol. 63, no. 2, pp. 120-128, 2009.

[45] H. Akbarshahi, A. H. Rosendahl, G. Westergren-Thorsson, and R. Andersson, "Acute lung injury in acute pancreatitis-a waiting the big leap," Respiratory Medicine, vol. 106, no. 9, pp. 11991210, 2012.

[46] M. M. Murr, J. Yang, A. Fier et al., "Regulation of Kupffer cell TNF gene expression during experimental acute pancreatitis: The role of p38-MAPK, ERK1/2, SAPK/JNK, and NF- $\kappa \mathrm{B}$," Journal of Gastrointestinal Surgery, vol. 7, no. 1, pp. 20-25, 2003.

[47] A. Masamune and T. Shimosegawa, "Pancreatic stellate cells e multi-functional cells in the pancreas," Pancreatology, vol. 13, no. 2, pp. 102-105, 2013.

[48] K.-B. Hahm, J.-H. Kim, B.-M. You et al., "Induction of apoptosis with an extract of Artemisia asiatica attenuates the severity of cerulein-induced pancreatitis in rats," Pancreas, vol. 17, no. 2, pp. 153-157, 1998.
[49] R. Kang, M. T. Lotze, H. J. Zeh, T. R. Billiar, and D. Tang, "Cell death and DAMPs in acute pancreatitis," Molecular Medicine, vol. 20, no. 1, pp. 466-477, 2014.

[50] A. M. Kaiser, A. K. Saluja, A. Sengupta, M. Saluja, and M. L. Steer, "Relationship between severity, necrosis, and apoptosis in five models of experimental acute pancreatitis," American Journal of Physiology-Cell Physiology, vol. 269, no. 5, pp. C1295-C1304, 1995.

[51] M. Bhatia, M. A. Wallig, B. Hofbauer et al., "Induction of apoptosis in pancreatic acinar cells reduces the severity of acute pancreatitis," Biochemical and Biophysical Research Communications, vol. 246, no. 2, pp. 476-483, 1998.

[52] M. Bhatia, "Apoptosis versus necrosis in acute pancreatitis," American Journal of Physiology-Gastrointestinal and Liver Physiology, vol. 286, no. 2, pp. G189-G196, 2004.

[53] X. Zhao, J. Li, S. Zhu et al., "Rhein induces a necrosis-apoptosis switch in pancreatic acinar cells," Evidence-Based Complementary and Alternative Medicine, vol. 2014, Article ID 404853, 7 pages, 2014.

[54] Y. Yuan, Z. Gong, K. Lou, S. Tu, Z. Di, and J. Xu, "Effects and mechanisms of somatostatin analogs on apoptosis of pancreatic acinar cells in acute pancreatitis in mice," Journal of Gastroenterology and Hepatology, vol. 16, no. 6, pp. 683-688, 2001.

[55] R. J. Krieser and K. White, "Engulfment mechanism of apoptotic cells," Current Opinion in Cell Biology, vol. 14, no. 6, pp. 734-738, 2002.

[56] P. M. Henson, D. L. Bratton, and V. A. Fadok, "The phosphatidylserine receptor: A crucial molecular switch?” Nature Reviews Molecular Cell Biology, vol. 2, no. 8, pp. 627-633, 2001.

[57] G. M. Cohen, "Caspases: The executioners of apoptosis," Biochemical Journal, vol. 326, part 1, pp. 1-16, 1997.

[58] M. Bhatia, "Apoptosis of pancreatic acinar cells in acute pancreatitis: Is it good or bad?" Journal of Cellular and Molecular Medicine, vol. 8, no. 3, pp. 402-409, 2004.

[59] Y. Liu, X. Chen, J. Yu et al., "Deletion Of XIAP reduces the severity of acute pancreatitis via regulation of cell death and nuclear factor- $\kappa \mathrm{B}$ activity," Cell Death \& Disease, vol. 8, no. 3, p. e2685, 2017.

[60] A. S. Gukovskaya, I. Gukovsky, Y. Jung, M. Mouria, and S. J. Pandol, "Cholecystokinin induces caspase activation and mitochondrial dysfunction in pancreatic acinar cells. Roles in cell injury processes of pancreatitis," The Journal of Biological Chemistry, vol. 277, no. 25, pp. 22595-22604, 2002.

[61] Y. Nakamura, J. H. Do, J. Yuan et al., "Inflammatory cells regulate p53 and caspases in acute pancreatitis," American Journal of Physiology-Gastrointestinal and Liver Physiology, vol. 298, no. 1, pp. G92-G100, 2010.

[62] Y. Lin, W. Ma, and S. Benchimol, "Pidd, a new death-domaincontaining protein, is induced by $\mathrm{p} 53$ and promotes apoptosis," Nature Genetics, vol. 26, no. 1, pp. 122-125, 2000.

[63] A. Tinel and J. Tschopp, "The PIDDosome, a protein complex implicated in activation of caspase- 2 in response to genotoxic stress," Science, vol. 304, no. 5672, pp. 843-846, 2004.

[64] P.-K. Ho, A. M. Jabbour, P. G. Ekert, and C. J. Hawkins, "Caspase-2 is resistant to inhibition by inhibitor of apoptosis proteins (IAPs) and can activate caspase-7," FEBS Journal, vol. 272, no. 6, pp. 1401-1414, 2005.

[65] C. M. Troy and M. L. Shelanski, "Caspase-2 redux," Cell Death \& Differentiation, vol. 10, no. 1, pp. 101-107, 2003. 
[66] S. Yang, X. Zhao, H. Xu et al., "AKT2 blocks nucleus translocation of apoptosis-inducing factor (AIF) and endonuclease $\mathrm{G}$ (EndoG) while promoting caspase activation during cardiac ischemia," International Journal of Molecular Sciences, vol. 18, no. 3, article 565, 2017.

[67] S. He, L. Wang, L. Miao et al., "Receptor interacting protein kinase-3 determines cellular necrotic response to TNF- $\alpha$," Cell, vol. 137, no. 6, pp. 1100-1111, 2009.

[68] N. Vanlangenakker, T. V. Berghe, and P. Vandenabeele, "Many stimuli pull the necrotic trigger, an overview," Cell Death \& Differentiation, vol. 19, no. 1, pp. 75-86, 2012.

[69] M. Sendler, J. Mayerle, and M. M. Lerch, "Necrosis, apoptosis, necroptosis, pyroptosis: it matters how acinar cells die during pancreatitis," Cellular and Molecular Gastroenterology and Hepatology, vol. 2, no. 4, pp. 407-408, 2016.

[70] J. M. Louhimo, M. L. Steer, and G. Perides, "Necroptosis is an important severity determinant and potential therapeutic target in experimental severe pancreatitis," Cellular and Molecular Gastroenterology and Hepatology, vol. 2, no. 4, pp. 519-535, 2016.

[71] H. Guo, J. B. Callaway, and J. P.-Y. Ting, "Inflammasomes: mechanism of action, role in disease, and therapeutics," Nature Medicine, vol. 21, no. 7, pp. 677-687, 2015.

[72] S. B. Kovacs and E. A. Miao, "Gasdermins: effectors of pyroptosis,” Trends in Cell Biology, vol. 27, no. 9, pp. 673-684, 2017.

[73] R. Hoque, M. Sohail, A. Malik et al., “TLR9 and the NLRP3 inflammasome link acinar cell death with inflammation in acute pancreatitis," Gastroenterology, vol. 141, no. 1, pp. 358-369, 2011.

[74] R. Hoque and W. Z. Mehal, "Inflammasomes in pancreatic physiology and disease," American Journal of Physiology-Gastrointestinal and Liver Physiology, vol. 308, no. 8, pp. G643G651, 2015.

[75] D. N. Criddle, J. V. Gerasimenko, H. K. Baumgartner et al., "Calcium signalling and pancreatic cell death: Apoptosis or necrosis?" Cell Death \& Differentiation, vol. 14, no. 7, pp. 1285-1294, 2007.

[76] T. Wieder, F. Essmann, A. Prokop et al., "Activation of caspase-8 in drug-induced apoptosis of B-lymphoid cells is independent of CD95/Fas receptor-ligand interaction and occurs downstream of caspase-3," Blood, vol. 97, no. 5, pp. 1378-1387, 2001.

[77] Y. Lin, A. Devin, Y. Rodriguez, and Z.-G. Liu, "Cleavage of the death domain kinase RIP by Caspase- 8 prompts TNF-induced apoptosis," Genes \& Development, vol. 13, no. 19, pp. 2514-2526, 1999.

[78] J. L. Evans, I. D. Goldfine, B. A. Maddux, and G. M. Grodsky, "Are oxidative stress-activated signaling pathways mediators of insulin resistance and $\beta$-cell dysfunction?" Diabetes, vol. 52, no. 1, pp. 1-8, 2003.

[79] S. Lenzen, J. Drinkgern, and M. Tiedge, "Low antioxidant enzyme gene expression in pancreatic islets compared with various other mouse tissues," Free Radical Biology \& Medicine, vol. 20, no. 3, pp. 463-466, 1996.

[80] T. Inaba, E. Kobayashi, Y. Suwazono et al., "Estimation of cumulative cadmium intake causing Itai-itai disease," Toxicology Letters, vol. 159, no. 2, pp. 192-201, 2005.

[81] C. M. Cuthbertson and C. Christophi, "Disturbances of the microcirculation in acute pancreatitis," British Journal of Surgery, vol. 93, no. 5, pp. 518-530, 2006.

[82] M. T. Toyama, M. P. N. Lewis, A. M. Kusske, P. U. Reber, S. W. Ashley, and H. A. Reber, "Ischaemia-reperfusion mechanisms in acute pancreatitis," Scandinavian Journal of Gastroenterology, vol. 31, no. 219, pp. 20-23, 1996.
[83] C. Shi, X. Zhao, X. Wang, and R. Andersson, "Role of nuclear factor- $\kappa \mathrm{B}$, reactive oxygen species and cellular signaling in the early phase of acute pancreatitis," Scandinavian Journal of Gastroenterology, vol. 40, no. 1, pp. 103-108, 2005.

[84] M. Bhatia, J. N. Sidhapuriwala, S. Wei Ng, R. Tamizhselvi, and S. M. Moochhala, "Pro-inflammatory effects of hydrogen sulphide on substance P in caerulein-induced acute pancreatitis," Journal of Cellular and Molecular Medicine, vol. 12, no. 2, pp. 580-590, 2008.

[85] B. M. Yoo, M. Yeo, T. Y. Oh et al., "Amelioration of pancreatic fibrosis in mice with defective TGF- $\beta$ signaling," Pancreas, vol. 30, no. 3, pp. e71-e79, 2005.

[86] W.-L. Cao, X.-H. Xiang, K. Chen, W. Xu, and S.-H. Xia, "Potential role of NADPH oxidase in pathogenesis of pancreatitis," World Journal of Gastrointestinal Pathophysiology, vol. 5, no. 3, pp. 169-177, 2014.

[87] S. W. Tsang, S. P. Ip, and P. S. Leung, "Prophylactic and therapeutic treatments with AT1 and AT 2 receptor antagonists and their effects on changes in the severity of pancreatitis," The International Journal of Biochemistry \& Cell Biology, vol. 36, no. 2, pp. 330-339, 2004.

[88] S. Stigliano, L. Archibugi, G. Zerboni, G. Delle Fave, and G. Capurso, "The use of complementary and alternative medicine is frequent in patients with pancreatic disorders," Journal of Clinical Gastroenterology, vol. 50, supplement 2, pp. S161-S163, 2016.

[89] M. Zhao, D.-B. Xue, B. Zheng, W.-H. Zhang, S.-H. Pan, and B. Sun, "Induction of apoptosis by artemisinin relieving the severity of inflammation in caerulein-induced acute pancreatitis," World Journal of Gastroenterology, vol. 13, no. 42, pp. 5612-5617, 2007.

[90] Y. Cen, C. Liu, X. Li et al., "Artesunate ameliorates severe acute pancreatitis (SAP) in rats by inhibiting expression of proinflammatory cytokines and Toll-like receptor 4," International Immunopharmacology, vol. 38, pp. 252-260, 2016.

[91] X.-P. Zhang, H. Tian, Y.-H. Lai et al., "Protective effects and mechanisms of Baicalin and octreotide on renal injury of rats with severe acute pancreatitis," World Journal of Gastroenterology, vol. 13, no. 38, pp. 5079-5089, 2007.

[92] Z. Xiping, T. Hua, Z. Jie et al., "Influence of baicalin on TNF$\alpha$ mRNA, caspase- 3 and $\mathrm{p}$-selectin expression in pancreatic tissue of rats with severe acute pancreatitis," Indian Journal of Gastroenterology, vol. 28, no. 4, pp. 131-135, 2009.

[93] T. Hua, Z. Xiping, W. Chengjun et al., "Effects of baicalin and octreotide on the serum tnf- $\alpha$ level and apoptosis in multiple organs of rats with severe acute pancreatitis," Inflammation, vol. 32, no. 3, pp. 191-201, 2009.

[94] X. Zhang, G. Feng, J. Jiang et al., "Effect of baicalin and octreotide on the expression levels of P-selectin protein in multiple organs of rats with severe acute pancreatitis," Journal of Gastroenterology and Hepatology, vol. 24, no. 11, pp. 1753-1762, 2009.

[95] Y. Cao, S. Adhikari, M.-V. Clément, M. Wallig, and M. Bhatia, "Induction of apoptosis by crambene protects mice against acute pancreatitis via anti-inflammatory pathways," The American Journal of Pathology, vol. 170, no. 5, pp. 1521-1534, 2007.

[96] N. M. Shafik and G. M. Abou-Fard, "Ameliorative effects of curcumin on fibrinogen-like protein-2 gene expression, some oxido-inflammatory and apoptotic markers in a rat model of 1arginine-induced acute pancreatitis," Journal of Biochemical and Molecular Toxicology, vol. 30, no. 6, pp. 302-308, 2016. 
[97] K. Zhong, "Curcumin mediates a protective effect via TLR$4 / \mathrm{NF}-\kappa \mathrm{B}$ signaling pathway in rat model of severe acute pancreatitis," Cell Biochemistry and Biophysics, vol. 73, no. 1, pp. 175180, 2015.

[98] A. Gulcubuk, D. Haktanir, A. Cakiris et al., "Effects of curcumin on proinflammatory cytokines and tissue injury in the early and late phases of experimental acute pancreatitis," Pancreatology, vol. 13, no. 4, pp. 347-354, 2013.

[99] W.-G. Yu, G. Xu, G.-J. Ren et al., "Preventive action of curcumin in experimental acute pancreatitis in mouse," Indian Journal of Medical Research, vol. 134, no. 11, pp. 717-724, 2011.

[100] I. Gukovsky, C. N. Reyes, E. C. Vaquero, A. S. Gukovskaya, and S. J. Pandol, "Curcumin ameliorates ethanol and nonethanol experimental pancreatitis," American Journal of PhysiologyGastrointestinal and Liver Physiology, vol. 284, no. 1, pp. G85G95, 2003.

[101] K. H. Chen, D. Chao, C. F. Liu, C. F. Chen, and D. Wang, "Curcumin attenuates airway hyperreactivity induced by Ischemiareperfusion of the pancreas in rats," Transplantation Proceedings, vol. 42, no. 3, pp. 744-747, 2010.

[102] J. X. Wu, J. Y. Xu, and Y. Z. Yuan, "Effects and mechanism of emodin and sandostatin on pancreatic ischemia in acute haemorrhagic necrotizing pancreatitis," Chinese Journal of Integrated Traditional and Western Medicine, vol. 17, no. 6, pp. 356-359, 1997.

[103] J.-X. Wu, J.-Y. Xu, and Y.-Z. Yuan, "Effect of emodin and sandostatin on metabolism of eicosanoids in acute necrotizing pancreatitis," World Journal of Gastroenterology, vol. 6, no. 2, pp. 293-294, 2000.

[104] X.-M. Xia, B.-K. Li, S.-M. Xing, and H.-L. Ruan, "Emodin promoted pancreatic claudin-5 and occludin expression in experimental acute pancreatitis rats," World Journal of Gastroenterology, vol. 18, no. 17, pp. 2132-2139, 2012.

[105] X.-M. Xia, F.-Y. Wang, Z.-K. Wang, H.-J. Wan, W.-A. Xu, and H. Lu, "Emodin enhances alveolar epithelial barrier function in rats with experimental acute pancreatitis," World Journal of Gastroenterology, vol. 16, no. 24, pp. 2994-3001, 2010.

[106] C.-H. Wang, Z.-Q. Gao, B. Ye et al., "Effect of emodin on pancreatic fibrosis in rats," World Journal of Gastroenterology, vol. 13, no. 3, pp. 378-382, 2007.

[107] Y. Li, F. He, Z. Huang, P. Xue, and Q. Xia, "Protective effects of emodin on intestinal lesion in rat model with acute necrotizing pancreatitis," Sichuan Da Xue Xue Bao. Yi Xue Ban, vol. 41, no. 6, pp. 1012-1015, 2010.

[108] W.-Y. Yao, Y.-F. Zhou, A.-H. Qian et al., "Emodin has a protective effect in cases of severe acute pancreatitis via inhibition of nuclear factor- $\kappa \mathrm{B}$ activation resulting in antioxidation," Molecular Medicine Reports, vol. 11, no. 2, pp. 1416-1420, 2015.

[109] Q. Ni, K. Sun, G. Chen, and D. Shang, "In vitro effects of emodin on peritoneal macrophages that express membranebound CD14 protein in a rat model of severe acute pancreatitis/systemic inflammatory response syndrome," Molecular Medicine Reports, vol. 9, no. 1, pp. 355-359, 2014.

[110] Q. Ni, W. Zhang, K. Sun, C. Yin, J. An, and D. Shang, "In vitro effects of emodin on peritoneal macrophage intercellular adhesion molecule- 3 in a rat model of severe acute pancreatitis/ systemic inflammatory response syndrome," Biomedical Reports, vol. 2, no. 1, pp. 63-68, 2014.

[111] J. Xu, B. Huang, Y. Wang et al., "Emodin ameliorates acute lung injury induced by severe acute pancreatitis through the upregulated expressions of AQP1 and AQP5 in lung," Clinical and
Experimental Pharmacology and Physiology, vol. 43, no. 11, pp. 1071-1079, 2016.

[112] J.-W. Ning, F. Ji, D.-D. Luo, C.-Y. Yang, and L.-J. Wang, "Effects of emodin on cell apoptosis of intestinal mucosa and serum leptin in rats with severe acute pancreatitis," Zhong Xi Yi Jie He Xue Bao, vol. 7, no. 12, pp. 1167-1173, 2009.

[113] L. Wu, B. Cai, X. Liu, and H. Cai, "Emodin attenuates calcium overload and endoplasmic reticulum stress in AR42J rat pancreatic acinar cells," Molecular Medicine Reports, vol. 9, no. 1, pp. 267-272, 2014.

[114] X.-P. Zhang, Z.-F. Li, X.-G. Liu et al., "Effects of emodin and baicalein on rats with severe acute pancreatitis," World Journal of Gastroenterology, vol. 11, no. 14, pp. 2095-2100, 2005.

[115] G. Wang, B. Sun, Y. Gao, Q. H. Meng, and H. C. Jiang, "The effect of emodin-assisted early enteral nutrition on severe acute pancreatitis and secondary hepatic injury," Mediators of Inflammation, vol. 2007, Article ID 29638, 8 pages, 2007.

[116] F. N. Köksoy, Y. Yankol, E. Şen Oran et al., "Preventive effects of enoxaparin and hesperidin in cerulein-induced acute pancreatitis in rats," The Turkish Journal of Gastroenterology, vol. 24, no. 6, pp. 495-501, 2013.

[117] J. Zhao, W. Tang, J. Wang, J. Xiang, H. Gong, and G. Chen, "Pharmacokinetic and pharmacodynamic studies of four major phytochemical components of da-cheng-qi decoction to treat acute pancreatitis," Journal of Pharmacological Sciences, vol. 122, no. 2, pp. 118-127, 2013.

[118] Y. Zhang, L. Zhu, J. Wang et al., "Formula compatibility identification of Dachengqi Decoction based on the effects of absorbed components in cerulein-injured pancreatic AR42J cells," Evidence-Based Complementary and Alternative Medicine, vol. 2016, Article ID 3198549, 8 pages, 2016.

[119] J. Chen, J. Chen, X. Wang et al., "Ligustrazine alleviates acute pancreatitis by accelerating acinar cell apoptosis at early phase via the suppression of p38 and Erk MAPK pathways," Biomedicine \& Pharmacotherapy, vol. 82, pp. 1-7, 2016.

[120] X. P. Wang, J. Y. Xu, and Y. Z. Yuan, "Therapeutic effects and mechanisms of tetramethylpyrazine on lung injury in acute haemorrhagic necrotizing pancreatitis in rats," Chinese Journal of Integrated Traditional and Western Medicine, vol. 13, no. 10, pp. 581-612, 1993.

[121] H. Wang and S. Zhang, "The intervention effects of different drugs on dendritic cells in acute pancreatitis in mouse," Zhongguo Wei Zhong Bing Ji Jiu Yi Xue, vol. 22, no. 4, pp. 201-205, 2010.

[122] U. M. Mahajan, C. Gupta, P. R. Wagh, P. A. Karpe, and K. Tikoo, "Alteration in inflammatory/apoptotic pathway and histone modifications by nordihydroguaiaretic acid prevents acute pancreatitis in swiss albino mice," Apoptosis, vol. 16, no. 11, pp. 1138-1149, 2011.

[123] Y. Meng, Q.-Y. Ma, X.-P. Kou, and J. Xu, "Effect of resveratrol on activation of nuclear factor kappa-B and inflammatory factors in rat model of acute pancreatitis," World Journal of Gastroenterology, vol. 11, no. 4, pp. 525-528, 2005.

[124] A. Szabolcs, I. S. Varga, C. Varga et al., "Beneficial effect of resveratrol on cholecystokinin-induced experimental pancreatitis," European Journal of Pharmacology, vol. 532, no. 1-2, pp. 187-193, 2006.

[125] Z.-H. Ma, Q.-Y. Ma, L.-C. Wang, H.-C. Sha, S.-L. Wu, and M. Zhang, "Effect of resveratrol on peritoneal macrophages in rats with severe acute pancreatitis," Inflammation Research, vol. 54, no. 12, pp. 522-527, 2005. 
[126] R. K. Jha, Q. Ma, Z. Lei, and H. Sha, "Resveratrol ameliorates the deleterious effect of severe acute pancreatitis," Cell Biochemistry and Biophysics, vol. 62, no. 2, pp. 397-402, 2012.

[127] R. K. Jha, Q. Ma, H. Sha, and M. Palikhe, "Protective effect of resveratrol in severe acute pancreatitis-induced brain injury," Pancreas, vol. 38, no. 8, pp. 947-953, 2009.

[128] Z.-D. Li, Q.-Y. Ma, and C.-A. Wang, "Effect of resveratrol on pancreatic oxygen free radicals in rats with severe acute pancreatitis," World Journal of Gastroenterology, vol. 12, no. 1, pp. 137-140, 2006.

[129] Z.-S. Lin, C. F. Ku, Y.-F. Guan et al., "Dihydro-resveratrol ameliorates lung injury in rats with cerulein-induced acute pancreatitis," Phytotherapy Research, vol. 30, no. 4, pp. 663-670, 2016.

[130] S. Sarwar, Z. Lin, C. Ku et al., "Protective effect of dihydroresveratrol against lung injury in rats with cerulein-induced acute pancreatitis," Planta Medica, vol. 81, no. S1, pp. S1-S381, 2016.

[131] J. Li, J. Zhang, Y. Fu et al., "Dual pancreas- and lung-targeting therapy for local and systemic complications of acute pancreatitis mediated by a phenolic propanediamine moiety," Journal of Controlled Release, vol. 212, pp. 19-29, 2015.

[132] F. F. Abreu, A. C. A. Souza, S. A. Teixeira et al., "Elucidating the role of oxidative stress in the therapeutic effect of rutin on experimental acute pancreatitis," Free Radical Research, vol. 50, no. 12, pp. 1350-1360, 2016.

[133] R. Aruna, A. Geetha, and P. Suguna, "Rutin modulates ASC expression in NLRP3 inflammasome: a study in alcohol and cerulein-induced rat model of pancreatitis," Molecular and Cellular Biochemistry, vol. 396, no. 1-2, pp. 269-280, 2014.

[134] R. Aruna, A. Geetha, and P. Suguna, "Expression of caspase activation recruitment and pyrin domain levels of apoptosis-associated speck-like protein complex in the pancreas of rats subjected to experimental pancreatitis: Influence of rutin administration," Human \& Experimental Toxicology, vol. 33, no. 9, pp. 940-948, 2014.

[135] Y. Y. Tu, M. Y. Ni, Y. R. Zhong et al., "Studies on the constituents of Artemisia annua L," Yao Xue Xue Bao, vol. 16, no. 5, pp. 366370, 1981.

[136] C. Sun and B. Zhou, "The molecular and cellular action properties of artemisinins: what has yeast told us?" Microbial Cell, vol. 3, no. 5, pp. 196-205, 2016.

[137] T. Efferth, "From ancient herb to modern drug: Artemisia annua and artemisinin for cancer therapy," Seminars in Cancer Biology, vol. 46, pp. 65-83, 2017.

[138] Y. Tu, "Artemisinin-a gift from traditional Chinese medicine to the world (nobel lecture)," Angewandte Chemie International Edition, vol. 55, no. 35, pp. 10210-10226, 2016.

[139] C. Shi, H. Li, Y. Yang, and L. Hou, "Anti-inflammatory and immunoregulatory functions of artemisinin and its derivatives," Mediators of Inflammation, vol. 2015, Article ID 435713, 7 pages, 2015.

[140] L.-L. Liu, L.-K. Gong, H. Wang et al., "Baicalin inhibits macrophage activation by lipopolysaccharide and protects mice from endotoxin shock," Biochemical Pharmacology, vol. 75, no. 4, pp. 914-922, 2008.

[141] Y.-X. Wu, E. Sato, W. Kimura, and N. Miura, "Baicalin and scutellarin are proteasome inhibitors that specifically target chymotrypsin-like catalytic activity," Phytotherapy Research, vol. 27, no. 9, pp. 1362-1367, 2013.
[142] M. J. Kang, G. S. Ko, D. G. Oh et al., "Role of metabolism by intestinal microbiota in pharmacokinetics of oral baicalin," Archives of Pharmacal Research, vol. 37, no. 3, pp. 371-378, 2014.

[143] K. Noh, Y. Kang, M. R. Nepal et al., "Role of intestinal microbiota in baicalin-induced drug interaction and its pharmacokinetics," Molecules, vol. 21, no. 3, p. 337, 2016.

[144] R. Staack, S. Kingston, M. A. Wallig, and E. H. Jeffery, "A comparison of the individual and collective effects of four glucosinolate breakdown products from Brussels sprouts on induction of detoxification enzymes," Toxicology and Applied Pharmacology, vol. 149, no. 1, pp. 17-23, 1998.

[145] S. Galletti, R. Bernardi, O. Leoni, P. Rollin, and S. Palmieri, "Preparation and biological activity of four epiprogoitrin myrosinase-derived products," Journal of Agricultural and Food Chemistry, vol. 49, no. 1, pp. 471-476, 2001.

[146] M. A. Wallig, D. H. Gould, and M. J. Fettman, "Selective pancreatotoxicity in the rat induced by the naturally occurring plant nitrile 1-cyano-2-hydroxy-3-butene," Food and Chemical Toxicology, vol. 26, no. 2, pp. 137-147, 1988.

[147] M. A. Wallig, D. H. Gould, J. Van Steenhouse, M. J. Fettman, and C. C. Willhite, "The relationship of vehicle to target organ toxicology induced by the naturally occurring nitrile 1-cyano2-hydroxy-3-butene," Fundamental and Applied Toxicology, vol. 12, no. 3, pp. 377-385, 1989.

[148] M. Maher, G. Chernenko, and J. A. Barrowman, "The acute pancreatotoxic effects of the plant nitrile 1-cyano-2-hydroxy-3butene," Pancreas, vol. 6, no. 2, pp. 168-174, 1991.

[149] M. A. Wallig and E. H. Jeffery, "Enhancement of pancreatic and hepatic glutathione levels in rats during cyanohydroxybutene intoxication," Fundamental and Applied Toxicology, vol. 14, no. 1, pp. 144-159, 1990.

[150] M. Wallig, A. M. Kore, J. Crawshaw, and E. H. Jeffery, "Separation of the toxic and glutathione-enhancing effects of the naturally occuring nitrile, cyanohydroxybutene," Toxicological Sciences, vol. 19, no. 4, pp. 598-606, 1992.

[151] Y. Cao, S. Adhikari, A. D. Ang, M. V. Clément, M. Wallig, and M. Bhatia, "Crambene induces pancreatic acinar cell apoptosis via the activation of mitochondrial pathway," American Journal of Physiology-Gastrointestinal and Liver Physiology, vol. 291, no. 1, pp. G95-G101, 2006.

[152] J. S. Jurenka, "Anti-inflammatory properties of curcumin, a major constituent of Curcuma longa: a review of preclinical and clinical research," Alternative Medicine Review, vol. 14, no. 2, pp. 141-153, 2009.

[153] A.-L. Chen, C.-H. Hsu, J.-K. Lin et al., "Phase I clinical trial of curcumin, a chemopreventive agent, in patients with high-risk or pre-malignant lesions," Anticancer Reseach, vol. 21, no. 4B, pp. 2895-2900, 2001.

[154] R. A. Sharma, S. A. Euden, S. L. Platton et al., "Phase I clinical trial of oral curcumin: biomarkers of systemic activity and compliance," Clinical Cancer Research, vol. 10, no. 20, pp. 6847-6854, 2004.

[155] M. H. Pan, T. M. Huang, and J. K. Lin, "Biotransformation of curcumin through reduction and glucuronidation in mice," Drug Metabolism \& Disposition, vol. 27, no. 4, pp. 486-494, 1999.

[156] G. Shoba, D. Joy, T. Joseph, M. Majeed, R. Rajendran, and P. S. S. R. Srinivas, "Influence of piperine on the pharmacokinetics of curcumin in animals and human volunteers," Planta Medica, vol. 64, no. 4, pp. 353-356, 1998. 
[157] C.-H. Hsu and A.-L. Cheng, "Clinical studies with curcumin," Advances in Experimental Medicine and Biology, vol. 595, pp. 471-480, 2007.

[158] S. Durgaprasad, C. Ganesh Pai, Vasanthkumar, J. F. Alvres, Sanjeeva, and Namitha, "A pilot study of the antioxidant effect of curcumin in tropical pancreatitis," Indian Journal of Medical Research, vol. 122, no. 4, pp. 315-318, 2005.

[159] R. J. Poojari, "Embelin, a small molecule quinone with a coclinical power for castrateresistant prostate cancer," Frontiers in Pharmacology, vol. 5, p. 184, 2014.

[160] Z. Nikolovska-Coleska, L. Xu, Z. Hu et al., "Discovery of embelin as a cell-permeable, small-molecular weight inhibitor of XIAP through structure-based computational screening of a traditional herbal medicine three-dimensional structure database," Journal of Medicinal Chemistry, vol. 47, no. 10, pp. 2430-2440, 2004.

[161] The Ayurvedic Pharmacopoeia of India, Government of India Ministry of Health and Family Welfare Department of Ayush, 2011.

[162] M. Atlabachew, B. Mehari, S. Combrinck, and R. Mccrindle, "Single-step isolation of embelin using high-performance countercurrent chromatography and determination of the fatty acid composition of seeds of Embelia schimperi," Biomedical Chromatography, 2017.

[163] M. Edderkaoui, A. Lugea, H. Hui et al., "Ellagic acid and embelin affect key cellular components of pancreatic adenocarcinoma, cancer, and stellate cells," Nutrition and Cancer, vol. 65, no. 8, pp. 1232-1244, 2013.

[164] H. Wu, R. Panakanti, F. Li, and R. I. Mahato, "XIAP gene expression protects $\beta$-cells and human islets from apoptotic cell death," Molecular Pharmaceutics, vol. 7, no. 5, pp. 1655-1666, 2010.

[165] A. M. Schaible, H. Traber, V. Temml et al., "Potent inhibition of human 5-lipoxygenase and microsomal prostaglandin E2 synthase- 1 by the anti-carcinogenic and anti-inflammatory agent embelin," Biochemical Pharmacology, vol. 86, no. 4, pp. 476-486, 2013.

[166] D. Shrimali, M. K. Shanmugam, A. P. Kumar et al., "Targeted abrogation of diverse signal transduction cascades by emodin for the treatment of inflammatory disorders and cancer," Cancer Letters, vol. 341, no. 2, pp. 139-149, 2013.

[167] L. Wan, Z. Wang, and L. Zhou, "Protecting effects of emodin on multiorgan failure of rats with severe acute pancreatitis," Pancreas, vol. 38, no. 7, pp. 835-836, 2009.

[168] X. Lu, W. Xiao, X. Kang, J. Yu, and Z. Fan, "The effect of Chinese herbal medicine on non-biliogenic severe acute pancreatitis: a systematic review and meta-analysis," Journal of Ethnopharmacology, vol. 155, no. 1, pp. 21-29, 2014.

[169] A. Kumar, S. Dhawair, and B. B. Aggarwal, "Emodin (3-methyl1,6,8-trihydroxyanthraquinone) inhibits TNF-induced NF- $\kappa \mathrm{B}$ activation, I $\kappa \mathrm{B}$ degradation, and expression of cell surface adhesion proteins in human vascular endothelial cells," Oncogene, vol. 17, no. 7, pp. 913-918, 1998.

[170] S. Zhu, Y. Wang, X. Wang, J. Li, and F. Hu, "Emodin inhibits ATP-induced IL- $1 \beta$ secretion, ROS production and phagocytosis attenuation in rat peritoneal macrophages via antagonizing P2X7 receptor," Pharmaceutical Biology, vol. 52, no. 1, pp. 51-57, 2014.

[171] B. Wan, H. Fu, J. Yin, and F. Xu, "Efficacy of rhubarb combined with early enteral nutrition for the treatment of severe acute pancreatitis: a randomized controlled trial," Scandinavian Journal of Gastroenterology, vol. 49, no. 11, pp. 1375-1384, 2014.

[172] S.-H. Zheng, Q.-Y. Tong, Z.-Y. Zhu, Z.-Y. Li, and H. You, "Effect of Rhubarb administered via different routes on blood inflammatory cytokines levels of patients with severe acute pancreatitis," Zhongguo Wei Zhong Bing Ji Jiu Yi Xue, vol. 23, no. 7, pp. 437-438, 2011.

[173] B. E. Wang and S. Y. Zhao, "Treatment of acute hemorrhagicnecrotic pancreatitis," Zhonghua Nei Ke Za Zhi, vol. 27, no. 1, pp. 25-27, 70, 1988.

[174] A. Garg, S. Garg, L. J. D. Zaneveld, and A. K. Singla, "Chemistry and pharmacology of the Citrus bioflavonoid hesperidin," Phytotherapy Research, vol. 15, no. 8, pp. 655-669, 2001.

[175] S. Bharti, N. Rani, B. Krishnamurthy, and D. S. Arya, "Preclinical evidence for the pharmacological actions of naringin: a review," Planta Medica, vol. 80, no. 6, pp. 437-451, 2014.

[176] J. D. Lambert, R. T. Dorr, and B. N. Timmermann, "Nordihydroguaiaretic acid: A review of its numerous and varied biological activities," Pharmaceutical Biology, vol. 42, no. 2, pp. 149-158, 2004.

[177] J. Shen, K. Man, P. Huang et al., "Honokiol and magnolol as multifunctional antioxidative molecules for dermatologic disorders," Molecules, vol. 15, no. 9, pp. 6452-6465, 2010.

[178] Y. Zhao, Y. Liu, and K. Chen, "Mechanisms and clinical application of tetramethylpyrazine (an interesting natural compound isolated from ligusticum wallichii): current status and perspective," Oxidative Medicine and Cellular Longevity, vol. 2016, Article ID 2124638, 9 pages, 2016.

[179] D. Bensky, S. Clavey, and E. Stoger, Chinese Herbal Medicine Materia Medica, Eastland Press, Seattle, Wash, USA, 3rd edition, 2004.

[180] J. Li, S. Zhang, R. Zhou, J. Zhang, and Z.-F. Li, "Perspectives of traditional Chinese medicine in pancreas protection for acute pancreatitis," World Journal of Gastroenterology, vol. 23, no. 20, pp. 3615-3623, 2017.

[181] X. P. Zhang, C. Wang, D. J. Wu, M. L. Ma, and J. M. Ou, "Protective effects of ligustrazine, kakonein and Panax notoginsenosides on multiple organs in rats with severe acute pancreatitis," Methods and Findings in Experimental and Clinical Pharmacology, vol. 32, no. 9, pp. 631-644, 2010.

[182] Y.-C. Weng and J.-Q. Fan, "Protective effect of TMP on pancreas function of acute pancreatitis rats," Asian Pacific Journal of Tropical Medicine, vol. 8, no. 6, pp. 474-478, 2015.

[183] X.-P. Zhang, J. Jiang, Q.-H. Cheng et al., "Protective effects of Ligustrazine, Kakonein and Panax notoginsenoside on the small intestine and immune organs of rats with severe acute pancreatitis," Hepatobiliary \& Pancreatic Diseases International, vol. 10, no. 6, pp. 632-637, 2011.

[184] S.-C. Dang, J.-X. Zhang, J.-G. Qu, X.-Q. Wang, and X. Fan, "Ligustrazine alleviates gastric mucosal injury in a rat model of acute necrotizing pancreatitis," Hepatobiliary \& Pancreatic Diseases International, vol. 6, no. 2, pp. 213-218, 2007.

[185] J.-X. Zhang, S.-C. Dang, J.-G. Qu, and X.-Q. Wang, "Ligustrazine alleviates acute renal injury in a rat model of acute necrotizing pancreatitis," World Journal of Gastroenterology, vol. 12, no. 47, pp. 7705-7709, 2006.

[186] J.-X. Zhang and S.-C. Dang, "Ligustrazine alleviates acute lung injury in a rat model of acute necrotizing pancreatitis," Hepatobiliary \& Pancreatic Diseases International, vol. 5, no. 4, pp. 605-609, 2006. 
[187] L. Frémont, "Biological effects of resveratrol," Life Sciences, vol. 66, no. 8, pp. 663-673, 2000.

[188] L. Czakó, T. Takács, I. S. Varga et al., "Involvement of oxygenderived free radicals in L-arginine-induced acute pancreatitis," Digestive Diseases and Sciences, vol. 43, no. 8, pp. 1770-1777, 1998.

[189] R. K. Jha, Q. Ma, H. Sha, and M. Palikhe, "Emerging role of resveratrol in the treatment of severe acute pancreatitis," Frontiers in Bioscience, vol. 2, pp. 168-175, 2010.

[190] X.-P. Zhang, D.-R. Liu, and Y. Shi, "Study progress in therapeutic effects of traditional Chinese medicine monomer in severe acute pancreatitis.," Journal of Zhejiang University: Science B (Biomedicine \& Biotechnology), vol. 8, no. 2, pp. 147-152, 2007.

[191] S. W. Tsang, Y.-F. Guan, J. Wang, Z.-X. Bian, and H.-J. Zhang, "Inhibition of pancreatic oxidative damage by stilbene derivative dihydro-resveratrol: Implication for treatment of acute pancreatitis," Scientific Reports, vol. 6, Article ID 22859, 2016.

[192] F. S. El-Feraly, "Isolation, characterization, and synthesis of 3,5,4' -trihydroxybibenzyl from Cannabis sativa," Journal of Natural Products, vol. 47, no. 1, pp. 89-92, 1984.

[193] K. Fritzemeier and H. Kindl, “9,10-Dihydrophenanthrenes as phytoalexins of orchidaceae: biosynthetic studies in vitro and in vivo proving the route from 1-phenylalanine to dihydro-m-coumaric acid, dihydrostilbene and dihydrophenanthrenes," European Journal of Biochemistry, vol. 133, no. 3, pp. 545-550, 1983.

[194] A. Hambrock, C. B. D. O. Franz, S. Hiller et al., "Resveratrol binds to the sulfonylurea receptor (SUR) and induces apoptosis in a SUR subtype-specific manner," The Journal of Biological Chemistry, vol. 282, no. 5, pp. 3347-3356, 2007.

[195] F. Sawada, T. Inoguchi, H. Tsubouchi et al., "Differential effect of sulfonylureas on production of reactive oxygen species and apoptosis in cultured pancreatic $\beta$-cell line, MIN6," Metabolism, vol. 57, no. 8, pp. 1038-1045, 2008.

[196] A. Takahashi, K. Nagashima, A. Hamasaki et al., "Sulfonylurea and glinide reduce insulin content, functional expression of KATP channels, and accelerate apoptotic $\beta$-cell death in the chronic phase," Diabetes Research and Clinical Practice, vol. 77, no. 3, pp. 343-350, 2007.

[197] K. Maedler, R. D. Carr, D. Bosco, R. A. Zuellig, T. Berney, and M. Y. Donath, "Sulfonylurea induced $\beta$-cell apoptosis in cultured human islets," The Journal of Clinical Endocrinology \& Metabolism, vol. 90, no. 1, pp. 501-506, 2005.

[198] Z.-D. Li, Q.-Y. Ma, and Y.-H. Luo, "Effect of resveratrol-induced FasL up-regulation on the apoptosis of pancreatic acinar cells in rats with severe acute pancreatitis," Nan Fang Yi Ke Da Xue Xue Bao, vol. 29, no. 3, pp. 454-457, 2009.

[199] H. Sha, Q. Ma, R. K. Jha et al., "Resveratrol ameliorates hepatic injury via the mitochondrial pathway in rats with severe acute pancreatitis," European Journal of Pharmacology, vol. 601, no. 13, pp. 136-142, 2008.

[200] A. Gulcubuk, D. Haktanir, A. Cakiris et al., "The effects of resveratrol on tissue injury, oxidative damage, and pro-inflammatory cytokines in an experimental model of acute pancreatitis," Journal of Physiology and Biochemistry, vol. 70, no. 2, pp. 397-406, 2014.

[201] M. J. DiMagno, J. A. Williams, Y. Hao, S. A. Ernst, and C. Owyang, "Endothelial nitric oxide synthase is protective in the initiation of caerulein-induced acute pancreatitis in mice," American Journal of Physiology-Gastrointestinal and Liver Physiology, vol. 287, no. 1, pp. G80-G87, 2004.
[202] S. Cuzzocrea, E. Mazzon, L. Dugo et al., "Inducible nitric oxide synthase-deficient mice exhibit resistance to the acute pancreatitis induced by cerulein," Shock, vol. 17, no. 5, pp. 416-422, 2002.

[203] Oral Resveratrol to Prevent Post-ERCP Pancreatitis-Full Text View-ClinicalTrials.gov., https://clinicaltrials.gov/ct2/ show/NCT02947932.

[204] J. Li, S.-F. Zhu, X.-L. Zhao et al., "Metabolomic profiles illuminate the efficacy of Chinese herbal Da-Cheng-Qi decoction on acute pancreatitis in rats," Pancreatology, vol. 15, no. 4, pp. 337343, 2015.

[205] J. Zhao, J. Chen, W. Tang, L. Wan, W. Xiong, and L. Zhou, "Effect of Da-Cheng-Qi decoction on pancreatitis-associated lung injury in patients and anti-inflammatory responses in rat models," Pharmaceutical Biology, vol. 49, no. 10, pp. 1058-1064, 2011.

[206] M.-H. Wan, J. Li, W. Huang et al., "Modified Da-ChengQi Decoction reduces intra-abdominal hypertension in severe acute pancreatitis: a pilot study," Chinese Medical Journal, vol. 125, no. 11, pp. 1941-1944, 2012.

[207] Y.-M. Zhang, H.-Y. Ren, X.-L. Zhao et al., "Pharmacokinetics and pharmacodynamics of Da-Cheng-Qi decoction in the liver of rats with severe acute pancreatitis," World Journal of Gastroenterology, vol. 23, no. 8, pp. 1367-1374, 2017.

[208] J. Zhao, C. Zhong, Z. He, G. Chen, and W. Tang, "Effect of Da-Cheng-Qi decoction on pancreatitis-associated intestinal dysmotility in patients and in rat models," Evidence-Based Complementary and Alternative Medicine, vol. 2015, Article ID 895717, 7 pages, 2015.

[209] I. Erlund, T. Kosonen, G. Alfthan et al., "Pharmacokinetics of quercetin from quercetin aglycone and rutin in healthy volunteers," European Journal of Clinical Pharmacology, vol. 56, no. 8, pp. 545-553, 2000.

[210] E. U. Graefe, J. Wittig, S. Mueller et al., "Pharmacokinetics and bioavailability of quercetin glycosides in humans," The Journal of Clinical Pharmacology, vol. 41, no. 5, pp. 492-499, 2001.

[211] H. Schneider, R. Simmering, L. Hartmann, H. Pforte, and M. Blaut, "Degradation of quercetin-3-glucoside in gnotobiotic rats, associated with human intestinal bacteria," Journal of Applied Microbiology, vol. 89, no. 6, pp. 1027-1037, 2000.

[212] K.-Y. Su, C. Y. Yu, Y.-P. Chen, K.-F. Hua, and Y.-L. S. Chen, "3,4-Dihydroxytoluene, a metabolite of rutin, inhibits inflammatory responses in lipopolysaccharide-activated macrophages by reducing the activation of NF- $\kappa \mathrm{B}$ signaling," BMC Complementary and Alternative Medicine, vol. 14, article 21, 2014.

[213] E. Saldanha, N. N. Joseph, R. Ravi et al., "Polyphenols in the prevention of acute pancreatitis: preclinical observations," Polyphenols in Human Health and Disease, vol. 1, pp. 427-433, 2013.

[214] N. Bashir, V. Manoharan, and S. Miltonprabu, "Grape seed proanthocyanidins protects against cadmium induced oxidative pancreatitis in rats by attenuating oxidative stress, inflammation and apoptosis via Nrf-2/HO-1 signaling," The Journal of Nutritional Biochemistry, vol. 32, pp. 128-141, 2016.

[215] H. Zhang, C.-Z. Cai, X.-Q. Zhang et al., "Breviscapine attenuates acute pancreatitis by inhibiting expression of PKC $\alpha$ and NF- $\kappa \mathrm{B}$ in pancreas," World Journal of Gastroenterology, vol. 17, no. 14, pp. 1825-1830, 2011.

[216] H. Xiang, Q. Zhang, B. Qi et al., "Chinese herbal medicines attenuate acute pancreatitis: pharmacological activities and mechanisms," Frontiers in Pharmacology, vol. 8, article 216, 2017. 
[217] Z. Liu, J. Liu, K. Zhao et al., "Role of daphnetin in rat severe acute pancreatitis through the regulation of TLR4/NF$\kappa \mathrm{B}$ signaling pathway activation," American Journal of Chinese Medicine, vol. 44, no. 1, pp. 149-163, 2016.

[218] B. I. Babu, G. Malleo, T. Genovese et al., "Green tea polyphenols ameliorate pancreatic injury in cerulein-induced murine acute pancreatitis," Pancreas, vol. 38, no. 8, pp. 954-967, 2009.

[219] H. Mirzaei, A. Shakeri, B. Rashidi, A. Jalili, Z. Banikazemi, and A. Sahebkar, "Phytosomal curcumin: A review of pharmacokinetic, experimental and clinical studies," Biomedicine \& Pharmacotherapy, vol. 85, pp. 102-112, 2017.

[220] A. R. Neves, M. Lúcio, J. L. C. Lima, and S. Reis, "Resveratrol in medicinal chemistry: a critical review of its pharmacokinetics, drug-delivery, and membrane interactions," Current Medicinal Chemistry, vol. 19, no. 11, pp. 1663-1681, 2012. 


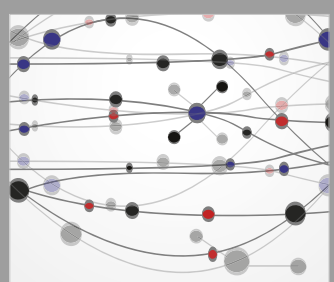

The Scientific World Journal
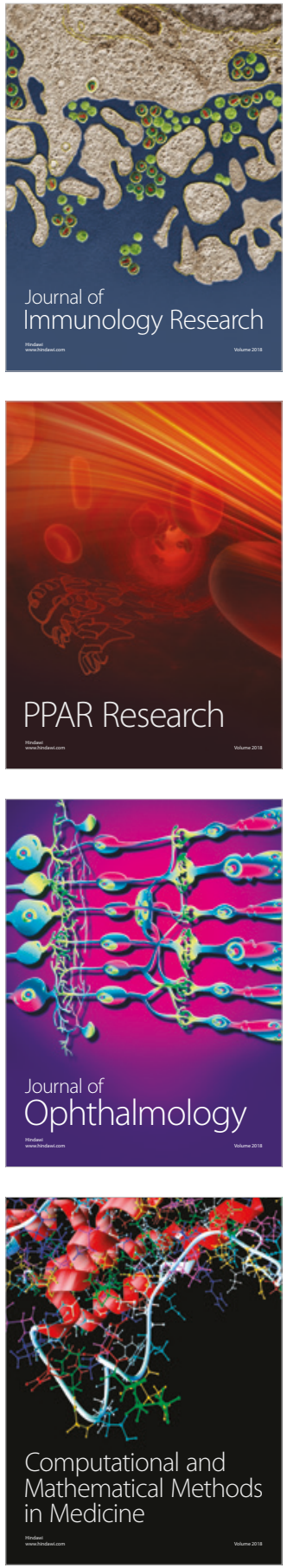

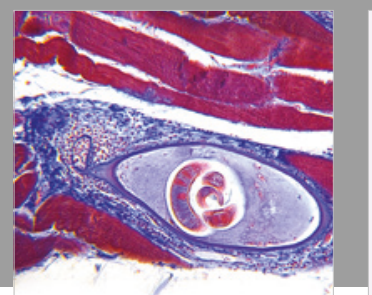

Gastroenterology Research and Practice

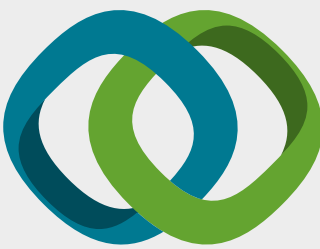

\section{Hindawi}

Submit your manuscripts at

www.hindawi.com
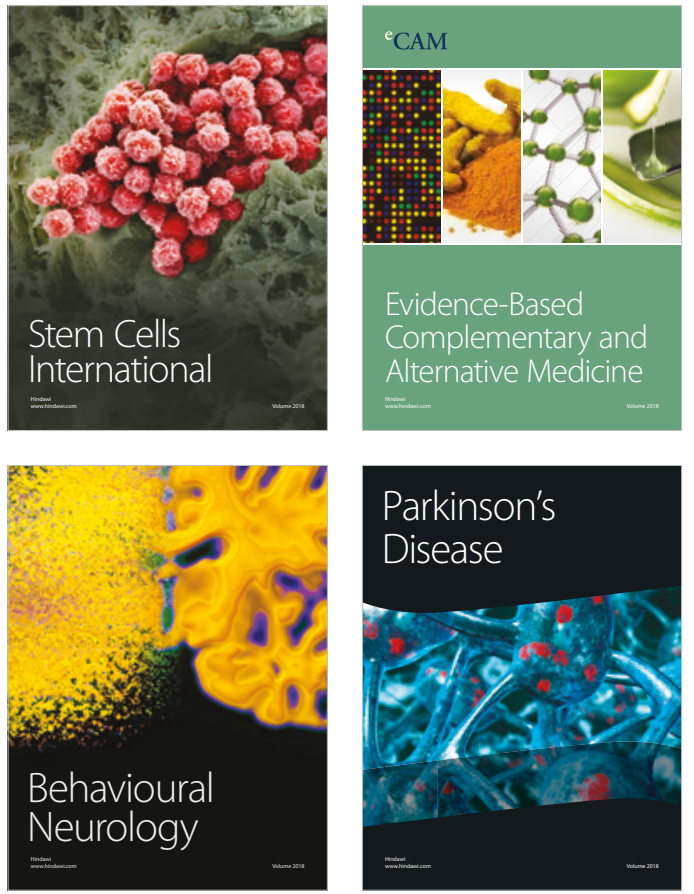

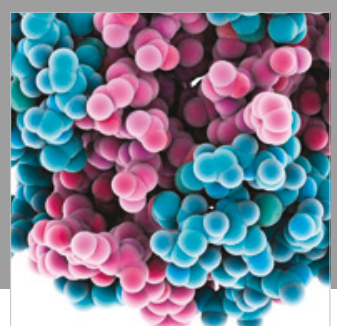

ournal of

Diabetes Research

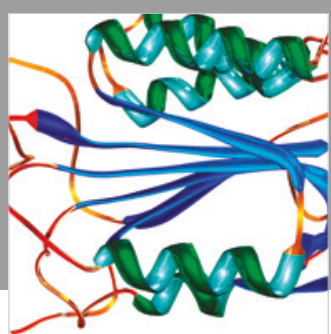

Disease Markers
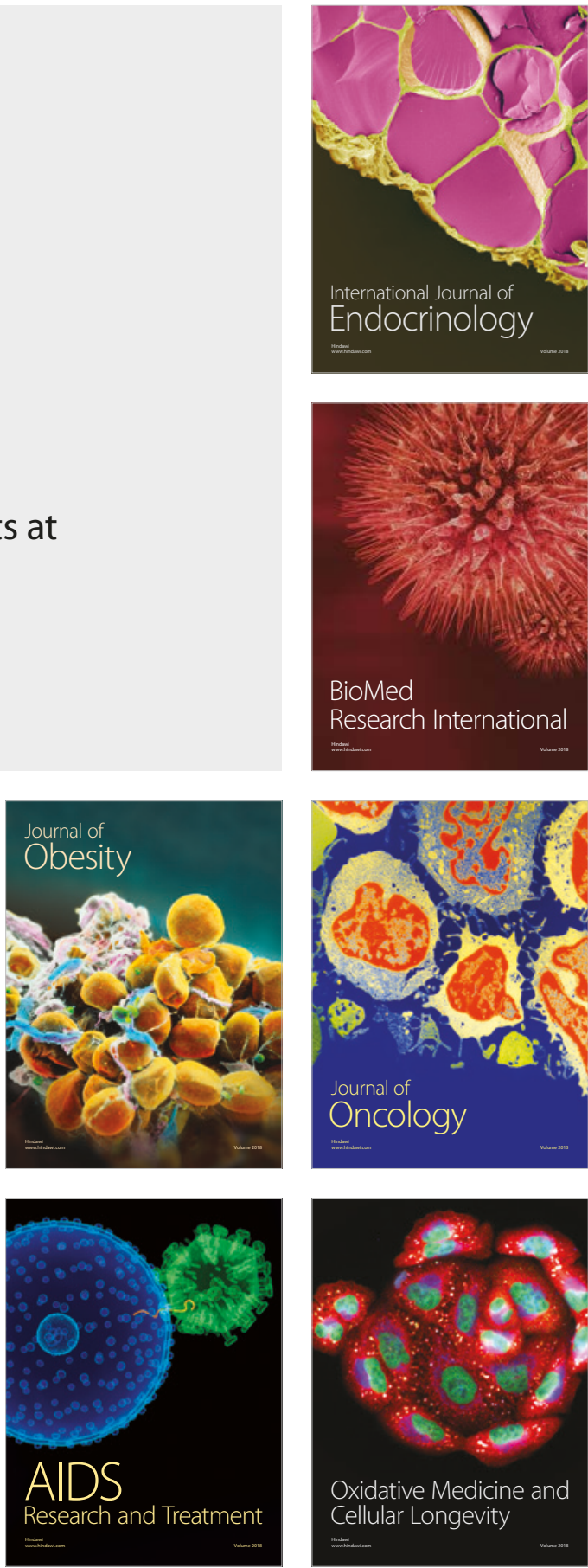